NBER WORKING PAPER SERIES

\title{
FLEXIBILITY AND JOB CREATION: LESSONS FOR GERMANY
}

\author{
James J. Heckman \\ Working Paper 9194 \\ http://www.nber.org/papers/w9194 \\ NATIONAL BUREAU OF ECONOMIC RESEARCH \\ 1050 Massachusetts Avenue \\ Cambridge, MA 02138 \\ September 2002
}

I thank Christina Gathmann of the University of Chicago for her comments and insights into the Germany economy. Pedro Carneiro provided additional useful comments. Thomas Bauer of IZA, Horst Siebert of the University of Kiel, Joachim Wagner of the University of Lüneburg, Rainer Winkelmann of IZA, and Klaus Zimmermann of IZA all provided very helpful information for which I am grateful. This paper was presented in a lecture at the Daimler-Chrysler center in Berlin, Germany, July 3, 2001. The views expressed herein are those of the author and not necessarily those of the National Bureau of Economic Research.

(C) 2002 by James J. Heckman. All rights reserved. Short sections of text, not to exceed two paragraphs, may be quoted without explicit permission provided that full credit, including (C) notice, is given to the source. 
Flexibility and Job Creation: Lessons for Germany

James J. Heckman

NBER Working Paper No. 9194

September 2002

JEL No. L5, J3, H2

\begin{abstract}
$\underline{\text { ABSTRACT }}$
This paper examines the performance of the German economy and the role of the regulation and welfare state policies in affecting its performance. While the German economy is still strong, incentives in place are likely to impair future German competitiveness and productivity.
\end{abstract}

James J. Heckman

Department of Economics

University of Chicago

1126 E. 59th Street

Chicago, IL 60637

and NBER

jjh@uchicago.edu 
I know from life and from history that ... often, the outward and visible material signs and symbols of happiness and success only show themselves when the process of decline has set in. The outer manifestations take time like the light of the star up there, which may in reality be already quenched when it looks to be shining brightest (Thomas Buddenbrooks to his sister Tony in Buddenbrooks, Part 7, Chapter 6). 


\section{Introduction}

The German economy lacks the robustness and vitality it possessed in the Erhard era. It is still a strong economy, competitive in medium-high technology trade, but it could be stronger. Unemployment is high, employment growth is low, and its competitive position in world trade is weak in areas of high technology, such as computers, communication technology, and biotechnology.

Germany's poor competitive position in high technology is a symptom of two interrelated factors. First, weak incentives to invest in skill (human capital) and venture capital, produced by the current level of regulation, taxation and bureaucratization. Second, the inability of the German system to respond to change rapidly. The new economy of the twenty-first century is characterized by variability and the need for flexible responses. This variability creates opportunity, but only for those able to respond quickly and with efficiency. It creates a demand for highly skilled labor and venture capital to respond to the new opportunities. The social system in Germany impedes rapid responses and hence thwarts the German economy from making use of the opportunities created by the new economy.

To understand the problems that beset the German economy and the possible solution to these problems, it is important to understand the causes of these problems more clearly and to distinguish the short-run from the long-run problems. In my view, it is the incentives in place that have long run consequences that are the most worrisome because they affect the way Germany will perform in the next generation. By the miracle of compound interest, large growth rates produce large wealth levels for future generations while low growth rates produce low wealth levels. Germans should be worried about these rates, although most political discussions focus only on the short run targets.

The immediate problem facing Germany and much of Europe is that of high unemployment rates. Thirty years ago, German unemployment rates were the envy of the world. They were one fifth of the U.S. unemployment rate, which was the same then as it is today. Thirty years later, German unemployment is roughly twice that of the U.S. rate. More generally, European unemployment has increased to extraordinarily high levels over the past 20 years. Something has changed and that something is not specific to 
Germany, but is common to many countries in Europe. Understanding that common factor, or set of factors, is the topic of a lot of recent research in economics. Despite appearances to the contrary, there is more agreement among economists than might first meet the eye. Contrary to public perception, professional economists who study European unemployment and the German economy agree on the basic forces underlying the high persistent unemployment in Germany and much of Europe.

There is a substantial body of empirical evidence pointing to the fact that incentives matter and that firms, individuals, and nations respond to them. Germans who remember the rigid incentives of the former East German economy do not have to be reminded that weak incentives can stifle productivity, investment, and effort. Less dramatically, incentives in Western economies to collect unemployment or disability benefits have been shown to have substantial effects in inducing people not to work and to go into beneficiary status. All economists looking at the empirical evidence accept this and the further point that the work disincentive effects of these programs are large. Disincentives imposed on firms such as minimum wages, union-imposed wage floors, or entry regulations have substantial effects especially when the minimums are binding. Studies from France, Latin America and Puerto Rico, where minimum wages are often a substantial fraction of average wages, as they are in Germany, have shown substantial disemployment effects of wage floors. Yet in the public discussion of employment creation these disemployment effects are minimized or ignored entirely.

Incentives motivate economic life. It is important to understand how the modern welfare state affects these incentives in order to understand why welfare states perform the way they do.

When the American economy is compared to the German and other European economies, it is not hard to reach the conclusion that it is something about incentives in the welfare state that gives rise to the differential performance of these two types of economies. This chapter is about those incentives, how they affect economic performance, and how incentives might be changed to improve that performance. I want to consider the economic consequences of these incentives in both the short and the long run. Elections are won on short-term performance, so politicians focus on short-run 
problems. However, as a detached scholar, I want to direct attention to the long-run issues: Nations prosper or founder on their long-run performance.

I make four main points and present empirical evidence to back them up, using references listed at the end of the chapter.

1. The incentives in European and German welfare states distort resource allocation and impair efficiency. The best estimates of the welfare cost of government activitywhat economists call deadweight burden-is 40 pfennigs for each mark raised by government activity, and some would place the cost even higher. These costs arise from the distortions in economic activity induced by the fiscal system. Much more than the direct cost of taxation is involved.

Centralized bargaining and regulation of business entry, banking practices, and employment all contribute to the burden. The levels of these disincentives are higher in Europe than in America, and this contributes to higher unemployment, lower employment growth, and a lower level of effort in the society. Such disincentive effects are much discussed in academic circles but they seem never to make their way into popular discussions of policy issues.

The benefit of the current system is alleged to be the universal social insurance it provides. According to this argument, the efficiency cost of taxation and regulation is to be set against the benefit of greater equity and security (Agell, 1999). A closer look at how the system works in Germany and many other European countries shows that it produces security and even wage gains for protected insiders at the cost of inequity, job loss, and income losses for outsiders who are only partially protected by social insurance. Far from promoting social justice at the price of efficiency, it provides security for some at the cost of exclusion for others.

2. The inefficiency and distortions created by the modern welfare state cannot explain the growth in European and German unemployment over the past 20 years. The edifice of the welfare state was in place 30 years ago, and arguably the incentives then were less favorable employment at that time than they are now (Ljungquist and Sargent, 1998; Blanchard and Wolfers, 2000). A vast empirical literature over the past 25 years has documented the distortions created by the welfare state. Many European governments reduced the worst of those incentive features in response to this literature but typically 
only by modest amounts. The reforms in Europe and Germany only partly close the incentive gap with America.

What is it then that accounts for the rise in European unemployment? This is the second major topic of this chapter. A growing body of evidence points to the fact that the world economy is more variable and less predictable today than it was 30 years ago when the modern European welfare state with its high levels of taxation and regulation was established. This variability is associated with the entry of many countries into world trade; with the creation of new financial markets and markets for goods; and with the explosion in technology, especially in computers, information technology, and biotechnology. This variability is associated with the onset of skill-biased technical change proceeding at an uneven and unpredictable pace that is still transforming the workplace and making traditional methods of production and management obsolete. Many empirical studies have shown that skill-biased technology is at work in advanced countries as well as Third World economies. These developments contribute to enormous increases in productivity in many industries and create new trading opportunities. At the same time, they lead to more variability and unpredictability in economic life. This variability is a source of wealth for those who can adapt to it. Figure 1 contrasts the distribution of outcomes in the less variable old economy with the distribution of outcomes in the new world economy.

The manifestations of the new variability are legion: rising wage inequality in markets favoring skilled workers in freely functioning labor markets, the large scale increase in merger activity, and patenting that occurred in the early $1980 \mathrm{~s}$ at the time of the rising wage inequality and the growth in volatility in trade and in some financial markets. The world has become more open and more fluid and at the same time many traditional methods and organizations have become obsolete.

We live in an era of creative destruction. The new order grows out of the old by destroying the old ways of producing goods and trading. This is an era of greater risk and greater return. The modern welfare state even at its newly "reformed" level is maladapted to this new world economy because it discourages risk taking and efficient adaptation by providing "social insurance" to preserve the status quo at precisely the time when many old economic practices are no longer productive. This explains why so many of the 
piecemeal reforms implemented in many welfare states around the world have apparently failed and have been associated with rising unemployment. These reforms would have promoted employment and reduced unemployment in a former era. In this modern era of change they do not go nearly far enough to make the reformed economies flexible enough to respond to the new and changing world economy. The world has been changing too fast for European politicians and policy makers keep up, and Europe will now have to run to keep in place.

An economic order that was well adapted to the more stable and predictable economic environment of the 1950s and 1960s has become dysfunctional in the late twentieth and early twenty-first centuries. The problem of unemployment in Germany is not due solely to the fact that the cost of labor is too high, although that is a problem (Bertola, 2000). It is also due to the inability of the economy to adapt to change and to exploit the opportunities and challenges of the new economy. The opportunity cost of security and preservation of the status quo - whether it is the status quo technology, the status quo trading partner, or the status quo job-has risen greatly in recent times.

3. The opening up of world trade and the increased competitiveness that flows from it means that now, more than ever before, uniformity in the prices of traded goods dictates labor market outcomes. Benefits given to workers are costs to firms and must be paid for in terms of lower wages or less employment. Something has to give in costs because market prices are set internationally and, increasingly, capital markets are uniform around the world. Thus nonwage mandates to workers nominally paid by firms must be borne by the workers themselves. Higher wages achieved by unions or by minimum wage statutes must lead to substitution against labor-fewer jobs—if firms are to remain competitive.

4. Hallmark features of the new economy are diversity, heterogeneity of opportunities, and value of local knowledge. One feature of the dynamics of the new order is that many idiosyncratic opportunities arise as potential trading partners and potential production partners seek each other out.

The old economics focused on stable technologies where broad aggregates such as capital and labor were assumed to be homogeneous. The economics of the modern era focuses on models of matching and sorting of heterogeneous individuals into trading and 
production units in the face of uncertainty about the suitability of any particular trading or production arrangement. This is a new model of the economy that features the unique and the relation specific. It is a model of marriage that emphasizes the value of partners that know each other in making the decisions to produce or trade and the value of divorce when circumstances change.

It is a model of the gains to trade among idiosyncratic individuals. The new model emphasizes the value of local knowledge and the benefit of exploiting local knowledge about particular possibilities and circumstances that are not widely known. The new economy emphasizes that one person's gain is not another person's loss and that economic efficiency is enhanced by allowing those equipped with local knowledge to act on it.

A striking example of the benefits of local knowledge is the reform of British unionism. When the locus of bargaining was shifted from the national and industry level to the firm level, the face of British unionism changed for the better (Pencavel, 2000). Firms and workers in Britain are now allowed to respond to the local opportunities and conditions that characterize their particular situation and can more freely adapt to those conditions than they could when national wage setting arrangements were in place. National or industry bargaining diverted the attention of workers away from the economic realities of their own productive situation and toward the redistributive possibilities that flow from the application of uniform rules across diverse industrial or national units. Not only does the implementation of local bargaining exploit local information and hence promote productivity but it also inhibits the application of monopoly and rent seeking that occurs when bargaining units become more expansive. Unionism per se is not a cause of inefficiency. Rather it is monopoly unionism using its power to redistribute resources and divert productive activity that leads to great harm.

In addressing these issues, I distinguish between long- and short-run problems and separate long-run solutions from short-run solutions that may be of no value, or even harmful, in the long-run. 


\section{German Unemployment and Wages}

The facts about German unemployment are well known. Unemployment is high and has been rising over the past 20 years (Bertola, 2001; Bean, 1994; Nickell, 1997). Lower than American employment 30 years ago, it is now much higher. See Figures 2, a and b, which compare OECD Europe with NorthAmerican overall unemployment rates. Figure 3 charts the temporal evolution of the German unemployment rate, which has been in the middle of the OECD pack. German unemployment, like most European unemployment, is largely made up of individuals suffering long spells. The unemployed are essentially removed from the labor market (see Figure 4). American unemployment is typically of much shorter duration and is associated with people changing jobs as opportunities appear and dissolve.

The rise in the unemployment rate in Germany is not due to an increase in employment or labor force participation rates. Prime age male employment rates are similar in the United States and in much of Europe. Overall employment rates in Europe and Germany are lower, a topic to which I return later. Unemployment rates are low among German youth (see Figure 5).

European unemployment is structural, not cyclical (Bertola, 2001) (see Figure 6). By this I mean that European-and German-employment is not amenable to the classical demand management policies of macroeconomics, although a few diehard Keynesians still push that line. The factors at work that produce higher levels of German unemployment are due to the economic fundamentals of incentives, technology, and labor supply.

One structural feature unique to Germany is the problem of the integration of East Germany. It is in fact remarkable that German unemployment rates are only in the middle of the European pack given the special circumstances of the East German case. Arguably, Germany would have one of the lower European unemployment rates were it not for the integration.

It is well documented that East German labor productivity was substantially lower than that in West Germany, and this difference was not due solely to differences in the technology between the two regimes. It is widely acknowledged that mandated wage parities between the regions contributed to unemployment and disemployment in the East 
and that they still play a substantial role in inhibiting employment growth in the former East German regions. These parities coupled with the work disincentives in the social insurance system account for the 2-1 ratio of East-West unemployment rates.

In understanding the problems of the East, it is important to account for the cohort-specific nature of the problem. In the eastern regions, there are substantial numbers of middle age workers educated and trained to work with an obsolete technology who cannot adapt to the new technology. Adapting these workers to the new social order is prohibitively expensive, although in 1989 official German policy was predicated on the belief that it was easy to retrain such workers.

One very well-established finding from the empirical literature in economics (Heckman, 2000; Heckman, et al., 1999) is that publicly supported job-training programs for displaced adult workers are ineffective. The economics of skill investment reveal that it is more efficient to invest in the young and the able than to invest in the middle-aged and the less able, where the returns to training have consistently been shown to be negligible. ${ }^{1}$ Competent empirical studies of these retraining programs for displaced Easterners have shown them to be failures (see Eicher and Lechner, 2000). In the short run, these policies reduce unemployment by making the unemployed persons trainees. In the long run, they are ineffective. Collecting the revenue to pay for these programs distorts the economy and diverts resources away from more socially useful opportunities.

This evidence, as well as the evidence from around the world, suggests that the East German problem is a cohort-specific one. A whole cohort of older workers caught up in the change is not well adapted to the modern technology, and training programs will not absorb them into the productive mainstream. Their children can be educated to be productive workers but they themselves cannot be. Two strategies for coping with this problem are: (1) to subsidize their employment and attach the workers to the economy with dignity by reducing the costs of these workers to firms while giving them an acceptable wage, or (2) to put them on the dole. Current overstated wage parities have forced option (2) onto the eastern Germany economy. These parities and the whole issue of wage subsidies should be examined carefully.

\footnotetext{
${ }^{1}$ They have fewer incentives to invest in new skills because of their shorter working lives and because it takes skill to produce skill (Heckman, 2000).
} 
In designing any such subsidies, it is necessary to make them cohort specific. They are a short-run solution to a short-run problem. The fathers and mothers should be subsidized but the children should be educated. If the children are subsidized, they will have no incentive to acquire skills.

The East German case is a dramatic example of a more general observation that characterizes markets in transition around the world. When new technology and opportunities become available, as they did in East Germany or in Argentina when it opened its markets to the new economy, it is the younger, more-educated, and more-able workers who benefit from the transition and the older, less-able, and less-educated workers who suffer the most. In Argentina, educated workers who would have been company presidents under the old regime were unemployed under the new one. The economic fundamentals suggest lower wages for such workers. A more humane social policy would pay them higher wages but subsidize firms for employing them. Economic policy must recognize the problem of the transition as an important feature of modern economies undergoing change.

The same forces are at work in all economies although in a less dramatic fashion. In the face of changes in technology and trading opportunities, it is the younger, the more educated, and the more able who benefit the most. The middle-aged and the older workers are at a disadvantage. Unless their wages adjust, they become unemployable.

This observation serves to explain why unemployment in Europe has increased across education and skill categories, especially among more experienced workers. As a consequence of rigidity in wages across the skill categories, these workers have become less employable. Economic policy should promote wage flexibility if it seeks to improve the employability of these workers. It should also reduce incentives to be unemployed from high-income replacement rates. Wage subsidies for the cohorts of workers caught up in the transition represent one option for improving their employment without reducing their standard of living (Snower, 1994; Phelps, 1997). Germans and other Europeans abhor the route of wage flexibility followed by the American economy, arguing that equity or social justice is as important, if not more important, than economic efficiency.

I do not want to tell Germans how to run their economy. Nor do I want to argue that European values placed on equality are inappropriate. However, I cannot help but 
note that the popular emphasis on "equity" and "social justice" is usually made in a factual void about the true costs of redistribution, which groups are targeted for social justice and which groups are excluded. It is certainly true that there is less inequality in earnings among workers in Germany and Europe than in the United States and in other economies with less rigid markets (see Table 1). At the same time, it is important to recognize that these statistics exclude the long-term unemployed, who constitute more than half of the unemployed in Germany. Accordingly, comparisons of income inequality between the United States and Germany exclude people with zero earnings and bias the comparisons, although this does not eliminate the gap in U.S.-German inequality. The long-term unemployed and the long-term dropouts are excluded from the accounting system of "social justice."

Implicit in many popular discussions of income inequality is the crude belief that one person's gain is another person's loss, that is, that the economic problem is a matter of dividing a fixed pie. In fact, the welfare state, at the level it currently operates in Germany, reduces the total social pie by discouraging production. It makes the size of the pie for the next generation smaller than it would otherwise be by discouraging investment in skills, technology, and knowledge. It discourages venture capital by taxing the proceeds of good investments and by regulating capital markets.

Going back to Figure 1, we see that the welfare state reduces the dispersion of social outcomes by reducing the level of social outcomes. How sizable is the cost in lost output? This is the crucial empirical question that is never asked or answered in public discussions. How much of the rise in German unemployment and the slow growth in output is due to institutions of the welfare state?

\section{The Causes of Joblessness}

In order to answer the question of what causes joblessness, it is useful to review the sharp contrast in the institutional features of German (and European) labor and product markets with those of American and other less regulated markets. The familiar picture that emerges is that European markets are much more regulated, wage setting is much more centralized and less adaptable to local conditions, and the replacement rate (the percentage of earnings an unemployed worker can claim) is much higher in Europe than 
in the United States. (See Figures 7, 8, and 9, respectively). The level of payroll taxation is substantially higher in Europe than in the United States (see Table 2). The tax wedge between what a firm pays per unit labor and what the worker receives is much greater in Europe than in the United States.

A large body of evidence suggests that at the current levels of incentives, the German welfare state reduces employment, raises unemployment, retards flexibility and creates a two-tier system, with a protected enclave surrounded by a partially protected group of unskilled, uneducated, and marginal workers (Siebert, 1997).

The high level of centralized wage bargaining thwarts the ability of workers and firms to act on local conditions and to bargain flexibly. Pencavel (1996) documents that the application of three principles - (1) decentralization of bargaining to the enterprise level; (2) removal of government intervention from the bargaining process; (3) local determination of the terms over which to bargain - promotes productivity and links payments to productivity in the workplace and not to politics. Studies of reforms of union systems in Great Britain, New Zealand, and Chile reveal that application of these principles to previously centralized wage-setting environments promoted productivity and raised wages in the aggregate. ${ }^{2}$

Detailed econometric studies by Nickell et al. (1992), Gregg et al. (1993), and Machin and Stewart (1996) demonstrate that substantial productivity growth occurred after decentralized unionism began to govern economic relations. The issue on the table is not about getting rid of unions; substantial productivity gains were registered at union plants when decentralized unionism was introduced. The issue is about making wage setting responsive to local conditions and to adapt to opportunities that appear. It has been shown that locally responsive unions facilitate plant-wide response to technical change (Levine, 1995). Decentralization improves adaptability, and the new economy places a premium on adaptability.

It is sometimes argued that centralized bargaining is beneficial and that unions can act in an enlightened way to correct any spillovers created by the action of local wage agreements. In theory, this is possible and experience with recent Dutch wage setting,

\footnotetext{
${ }^{2}$ While wage inequality rose in Great Britain during this period, so did real wages, and at a much faster rate than in the United States.
} 
until recently, illustrates that in a small country with few unions, it may be possible to make centralized bargaining work. However, as Pencavel demonstrates, the monopoly power created by centralization is too tempting not to use and the track record on centralized bargaining is poor, especially in large economies such as that of Germany.

Germany does not have a governmentally mandated minimum wage although union wage floors effectively operate as wage minimums. One measure of the effectiveness of a minimum wage is the ratio of the minimum to the average wage. This ratio is much higher in Germany, and continental Europe more generally, than it is in the United States or Great Britain (see Table 3). The higher this ratio, the more binding these minimums are on the operations of firms.

The French ratio is below that of Germany but much higher than that of the United States or Great Britain. A series of important papers by John Abowd (e.g., Abowd et al., 1997, 1999) and various co-authors documents the substantial disemployment effects of French minimum wages. Minimum wage effects are weak only when minimum wages do not bind. A widely cited study by Card and Krueger (1995) that claimed to find no disemployment effects of minimum wages has been challenged in the professional journals. Even if correct for the small wage changes studied in the United States, this study is irrelevant for Europe, which has much higher effective-and bindingminimums. Machin et al. (2000) demonstrates ho New Deal minimum-wage increases reduced employment in the home core sector in England

Some indirect evidence of the importance of the disemployment effects of the minimum wage is implicit in Figure 5. The lower rate of youth unemployment in Germany compared to that of many other countries is frequently attributed to the apprenticeship system. It is certainly true that a system that encourages youth to both work and learn promotes their immediate employment. A closer look at this system reveals that during the apprenticeship period, firms can pay apprentices wages that are substantially below the minimum wage. When the apprenticeship period ends, unionmandated minimum wages apply. It is no accident, then, that Germany is one of the few countries in the world to have a higher rate of unemployment among young adults (in their early 20s) not covered by the minimum-wage exemption than among teenage youth 
(Heckman et al., 1994). Reducing minimum wages substantially promotes employment in economies such as that of Germany, where minimum wages are high.

German replacement rates of the earnings of the unemployed by social insurance are substantial (see Figure 9). It is very well documented that higher levels of unemployment compensation induce greater rates of unemployment. (See the evidence summarized in Layard et al., 1999). As the generosity of benefits increases, so does the incentive not to work. Germans, like all people, respond to these incentives.

German levels of labor market regulation are high compared to those in the United States. Employment protection laws protect the status quo and make it difficult for firms to respond flexibly to changing market conditions and to improved technologies. Thus it is no accident that the unemployment-GDP growth relationship is weak in Germany compared to that of countries with more flexible labor markets. Figure 10 compares the change in the unemployment rate in response to GDP growth across a variety of countries. In economies where it is costly to fire workers, job growth in response to GDP growth is diminished since firms account for the possibility that the economy might turn sour in the future and employment protection laws make it difficult to fire redundant labor. Hence, they hire fewer workers to avoid having to pay the costs of possibly having to fire them. The other side of the coin, however, is that employment protection laws make slowdowns in GDP growth less costly in terms of unemployment. It protects the insiders against job loss.

The United States has a very flexible labor market compared to Germany. Nonetheless, substantial changes have recently been made to the "employment at will" doctrine that gave freedom to the employer to fire employees without any cost. This has moved the American system of severance pay closer to that of Europe. Union work rules impose some restrictions on U.S. firms, and the portion of the costs of unemployment insurance borne by the firm make work force reduction costly.

In the 1980s, many state judiciaries in the United States adopted "wrongful termination" doctrines. These doctrines impose substantial costs of employment termination on employers that are similar in character to severance cost payments in the German system. In what appears to be a natural experiment, it is possible to examine the 
consequences of these doctrines on employment. The effectiveness and comprehensive nature of the law vary from state to state.

While the direct legal costs of the new doctrines are relatively low, on average the whole process adds uncertainty to the employment process and some settlements are high (\$177,000 in U.S. 1998 dollars). Firms now play a lottery with the court system. Despite small average costs, the response of firms to the potential of experiencing a very visible wrongful termination case has been dramatic. Elaborate procedures have been established at all stages of the hiring and discharge process. Firms now institute more elaborate screening and review procedures when hiring and firing workers.

These costs have a potent negative effect on employment in states that adopt "wrongful termination" laws. Dertouzos and Karoly (1991) examine the employment consequences of these costs. The most severe systems, which in my view are lower bounds for the German case, suggest that employment declines by 5 percent in states with the most comprehensive employment protection legislation.

Employment protection laws in theory need not have any adverse effects on employment. The argument is that if a firm were mandated to offer a benefit such as job security to its workers, the latter would be willing to accept lower wages to obtain the benefit. The composition of the pay package would be affected even if the total level of compensation is not. For this argument to have any practical significance, wages have to be downward flexible. Yet Table 3 suggests that they are not. Binding minimum wages, whether imposed by national laws as in France or by union minimums as in Germany, prevent the necessary wage adjustments.

Evidence of the impact of employment protection legislation on employment and wage inequality suggests the following. Countries with more severe employment regulation legislation have lower employment rates (Figure 11) and less wage inequality among workers (Figure 12). Those who keep jobs stay at them longer (Figure 13). There is little effect of this legislation on the employment of prime age males (Figure 14).

The picture that emerges from this evidence is that the employment protection laws (EPL) create a protected enclave of insiders who experience less unemployment and wage fluctuations than the excluded outsiders. Social justice applies to this enclave but not to the entire society. Given that the long-term unemployed are excluded from the 
statistics on income inequality, international comparisons of income inequality such as those in Table 1 dramatically understate the inequality inherent in the European welfare state. 


\section{Restrictions in Other Markets}

When considering Germany's employment problems, the natural first impulse is to look at the institutions governing the labor market. Yet economists since the time of Alfred Marshall have recognized that the structure of the product and the capital markets affect the performance of the labor market.

The German product market is highly regulated, although it is far from the most regulated product market in Europe (see Figure 15). Product market regulation goes hand in glove with labor market regulation (see Figure 16) (Nicoletti and Scarpetta, 2001; Scarpetta, 1998). Inducing competition in the product market is one way of curbing excess union power. Price-taking firms offer smaller opportunities for rent seeking unions.

Regulation of the product market retards the responsiveness of the German economy to new trade and technology opportunities and inhibits job creation (Djankov et al., 2000). Table 4 compares the regulatory environment in Germany with that of the rest of the world. Compared to the United States, German firms are required to go through more procedures (seven vs. four) and take a longer time (90 vs. 7 days), and the process costs roughly ten times more in Germany than in the United States. By inhibiting entry and retarding flexibility, product market regulation reduces the demand for labor and the growth of jobs. This unfriendly regulatory environment also retards investment and risk taking. It inhibits German adaptation to the new economy. As an example, consider the relationship between Internet usage and EPL (see Figure 17). The more stringent the employment protection or business regulation laws, the less the use of the Internet (see Samaniego, 2001), which accounts for the lesser use of the Internet in Germany (see figure 18).

This unfriendly environment also helps to explain why, in recent years, the share of foreign direct investment in Germany has been so low (see Figure 19) and why German investment in venture capital is low (see Figure 20). It also accounts for why Germans have found investment abroad so attractive.

Reforms in the product market and in capital markets will promote flexibility and will facilitate reforms in the labor market. That is a lesson learned during many successful economic reforms around the world. 


\section{The Long-Run Consequences of Regulation and the Welfare State for Germany}

Product market and labor market regulation not only impede the flexibility of the German economy but also threaten its future vitality. These long-run effects are rarely debated in public because they operate in a subtle fashion and do not show up on the front pages of newspapers.

Trade is the engine of German economic power. Germany retains its strong competitive position in medium-high technology (e.g., traditional manufacturing). But it does not have comparative advantage in the cutting edge technologies of computers, information technology, and biotechnology (see Figure 21). The technology intensity of German exports is low by international standards (see Figure 22). The highly regulated capital markets have prevented German venture capital from flowing into these cuttingedge areas of world trade and technology (Siebert and Stolpe, 2001). As a consequence, German supremacy in trade in future world markets is at risk.

The high tax rates inherent in the German system and the rigidity of the educational system discourage skill formation. Since knowledge is created by educated people, the failure of German institutions of higher learning to produce more students and to develop flexible arrangements with industry bodes ill for the future of German technology.

\section{Summing Up}

The Germany economy labors under the burden of heavy regulation and weak incentives. The German welfare state has succeeded in raising the wages and benefits of protected insiders but at the cost of low employment growth, low productivity growth in the manufacturing sector, and higher unit labor costs (see Figures 24, 25, 26). These factors threaten the long-term competitive position of German industry in world trade and inhibit Germany from investing in the technologies of the future.

In analyzing German employment problems, I have stressed the importance of distinguishing long-run from short-run problems and long-run from short-run solutions. German unemployment is a structural problem. Some aspects of German unemployment will fade as older cohorts of workers trained under the East German system retire and are 
replaced by more educated workers adapted to the new system. Apart from this short-run feature a substantial portion of German unemployment is a symptom of the deeper problem that incentives to innovate, to acquire skills, and to take risks have been thwarted by the welfare state. The costs of preserving the status quo have increased in the new world economy that is characterized by many new opportunities in technology and trade. The winners in world trade in the next generation will be those countries that can respond flexibly with educated work forces.

I opened this chapter with a quotation from Thomas Mann's Buddenbrooks. In closing, let me explain its relevance. The German economy is, in many ways, still in robust health. Germany remains a major factor in the world economy. Germans have begun to shift toward making markets more flexible, unemployment benefits lower, and bargaining more decentralized. These reforms have only been partial in character and are not substantial enough to successfully adapt the German economy to the economy of the future.

In pursuit of social justice-which in actuality is a defense of a protected enclave of workers and firms - Germany has muted incentives to invest in ideas, skills, and new technology. These muted incentives portend a second-rate German economy in the future. While Germany is not yet Thomas Mann's dead star, sending forth its light, it will be a dying star if it fails to adapt to the new world economic order. 


\section{Sources}

Abowd, J., F, Kramarz, T. Lemieux and D. Margolis, "Minimum Wages and Youth Employment in France and The United States," National Bureau of Economic Reserarch Working Paper 6111, July 1997.

Abowd, J., F. Kramarz and D. Margolis, "Minimum wages and Employment in France and The United States," National Bureau of Economic Research Working Paper 6996, March, 1999.

Addison, J. and J. L. Grosso, "Job Security Provisions and Employment: Revised Estimates," Industrial Relations, 35(4), 1996, 585-603.

Agell, J., "On The Benefits From Rigid Labor Markets: Norms, Market Failures, and Social Insurance,” Economic Journal, 109, 1999, 143-164.

Bean, C., "European Unemployment: A Survey," Journal of Economic Literature, 32(2), 1994, 573-619.

Belot, M. and J. Van Ours, "Does The Recent Success of Some OCED Countries in Lowering Unemployment Lie In Their Clever Design of Labor Market Reforms?," IZA Working Paper, 147, April 2000.

Bertola, G., "Europe's Unemployment Problems," in Economics of The European Union, ed. by M. Artis and F. Nixson, ${ }^{2 n d}$ Edition, Oxford: Oxford University Press, 2000.

Bertola, G., "Aggregate and Disaggregated Aspects of Employment and Unemployment,” European University, April, 2001.

Bertola, G., F. Blau and L. Kahn, “Comparative Analysis of Labor Market

Outcomes: Lessons for the U.S. from International Long-Run Evidence," Russell Sage Foundation, New York, 2001.

Bertola, G. and R. Rogerson, "Institutions and Labor Reallocation,” European Economic Review, 41, 1997, 1147-1171.

Bertrand, M. and F. Kramarz, "Does Entry Hinder Job Creation? Evidence From The French Retail Industry,” NBER Working Paper 8211, April 2001.

Bierhanzl, E. and J. Gwartney, "Regulations, Unions and Labor Markets," Regulation, 21(3), 1998. 
Blanchard, O. and J. Wolfers., "The Role of Shocks and Institutions In The Rise of European Unemployment: The Aggregate Evidence," Economic Journal, 110, 2000, C1- C33.

Card, D. and A. Krueger, "Myth and Measurement: The New Economics of the Minimum Wage, Princeton: Princeton University Press, 1995.

Cox Edwards, A., "The Unemployment Effect of Labor Market Interventions," Argentina Labor Markets Study, World Bank, February, 1996.

Dertouzos, J. and L. Karoly, Labor Market Responses To Employer Liability, , Santa Monica, CA: Rand Corporation, Institute for Civil Justice, 1991.

Djankov, S., R. Laporta, F. Lopez and A. Shleifer, "Regulation of Entry," unpublished manuscript, Harvard University, Department of Economics, 2000.

Eicher, M. and M. Lechner, "Public Sector Sponsored Continuous Vocational Training in East Germany: Institutional Arrangements, Participants and Results of Empirical Studies," IZA Working Paper 76/2000.

Evans, L., A. Grimes, B. Wilkinson with D. Teece, "Economic Reform in New Zealand 1984-1995: The Pursuit of Efficiency," Journal of Economic Literature, 1996, 1856-1902.

Freeman, R., "Institutional Differences and Economic Performance Among OECD Countries," unpublished manuscript, Harvard University, 2001.

Fuchs, S. and R. Schettkat, "The Impact of Deregulation On The German Labor Market," unpublished manuscript, Humbolt University, Berlin, 1999.

Gregg, P., S. Machin and D. Metcalf, "Signals and Cycles? Productivity Growth and Change in Union Status in British Companies," Economic Journal, 1993, 854-907.

Guasch, L., "Estimating the Benefits of Labor Reform in Argentina," World Bank, May 24, 1996.

Heckman, J., "Policies to Foster Human Capital," Research in Economics, 54, 2000, 3-56.

Heckman, J., R. Roselius, and J. Smith, "U.S. Education and Training Policy: A Reevaluation of The Underlying Assumptions Behind The New Consensus," in A. Levenson and L. C. Solomon, eds., Labor Markets, Employment Policy and Job Creation. Santa Monica: Milken Institute for Job and Capital Formation, 1994. 
Heckman, J., R. LaLonde, and J. Smith, "The Economics of Econometrics of Active Labor Market Program," in Handbook of Labor Economics, Vol. 3, edited by O. Ashenfelter and D. Card, Elsevier Science, B. V. Amsterdam, 1999, 1865-2097.

Kasper, W., Free to Work The Liberalization of New Zealand's Labour Markets, Wellington, New Zealand, Centre for Independent Studies, 1996.

Kortum, Samuel and Joshua Lerner, Rand Journal of Economics, 2000.

Lazear, E., "Job Security Provisions and Employment," Quarterly Journal of Economics, 3, 1990, 699-726.

Layard, R. and S. Nickell, "Labor Market Institutions And Economic Performance," in Handbook of Labor Economics, Vol. 3C, edited by, O. Ashenfelter and D. Card, Amsterdam: North Holland, 1999.

Levine, D., Reinventing the Workplace. How Business and Employees Can Both Win, Brookings, Washington, 1995.

Ljungquist, L. and T. Sargent, "The European Unemployment Dilemma," Journal of Political Economy, 106(3), 1998, 514-550.

Machin, S. and M. Stewart, "Trade Unions and Financial Performance," Oxford Economic Papers 48, 1996, 213-241.

Mann, T., Buddenbrooks, translated by H. T. Lowe-Porter, New York, Alfred Knoff Publisher, 1924.

Menezes-Filho, N., "Unions and Profitability Over the 1980s: Some Evidence on Union Firm Bargaining in the U.K," Economic Journal, 107, 1997, 651-670.

Nickell, S., "Unemployment and Labor Market Rigidities: Europe vs. North America," Journal of Economic Perspectives, 11(3), 1997, 55-74.

Nickell, S. and B. Bell, "Changes in the Distribution of Wages and Unemployment in OECD Countries," American Economic Review, 1996, 302-308.

Nickell, S. S. Wadwahni, and M. Wall, "Productivity Growth in U.K. Companies: 1975-1986," European Economic Review, 36, 1992, 1055-1091.

Nickell, S., L. Nunziata, W. Ochel and G. Quintini, "The Beveridge Curve, Unemployment and Wages in the OECD from the $1960^{\mathrm{s}}$ to $1990^{\mathrm{s}}$," unpublished manuscript, London School of Economics, 2001. 
Nickell, S. and J. Van Ours, "Netherlands and the United Kingdom: A European Unemployment Miracle,?” Economic Policy, April 2000, 137-180.

Nicoletti, G. and S. Scarpetta, "Interactions Between Product and Labor Market Regulations: Do They Affect Employment? Evidence From OECD Countries," Banco Portugal Conference, June 3-4, Cascais, Portugal, 2001.

OECD Jobs Study: Evidence and Explanations, Parts I and II, Paris: Organization for Economic Cooperation and Development, 1994.

OECD Economic Outlook, Paris: Organization for Economic Cooperation and Development, 2000.

OECD Economic Surveys. Germany, Paris: Organization for Economic Cooperation and Development, May 2001.

Pencavel, J., "Selected International Experience Concerning the Legal Framework for Collective Bargaining and Unionism," unpublished manuscript, Stanford University, Palo Alto, CA, 1996.

, "The Surprising Retreat of Union Britain," unpublished manuscript, Stanford University, November 2000.

Samaniego, R., "Does Employment Protection Inhibit Technology Diffusion?," unpublished manuscript, University of Pennsylvania, Department of Economics, 2001.

Scarpetta, S., "Labor Market Reforms and Unemployment: Lessons From The Experience of The OECD Countries," IADB Working Paper 387, Washington, D.C, 1998.

Siebert, H., "Labor Market Rigidities: At The Root of Unemployment in Europe," Journal of Economic Perspectives, 11(3), 1997, 37-54.

Siebert, H. and M. Stolpe, "Technology and Economic Performance In Germany," Kiel Working Paper 1035, April, 2001.

Snower, D., "Converting Unemployment Benefits into Employment Subsidies," American Economic Review, 84(2), 1994, 65-70.

Stewart, M., "Union Wage Differentials, Product Market Influences and The Division of Rents," Economic Journal 100, 1990, 1122-1137. 
Figure 1.

Two alternative social orders

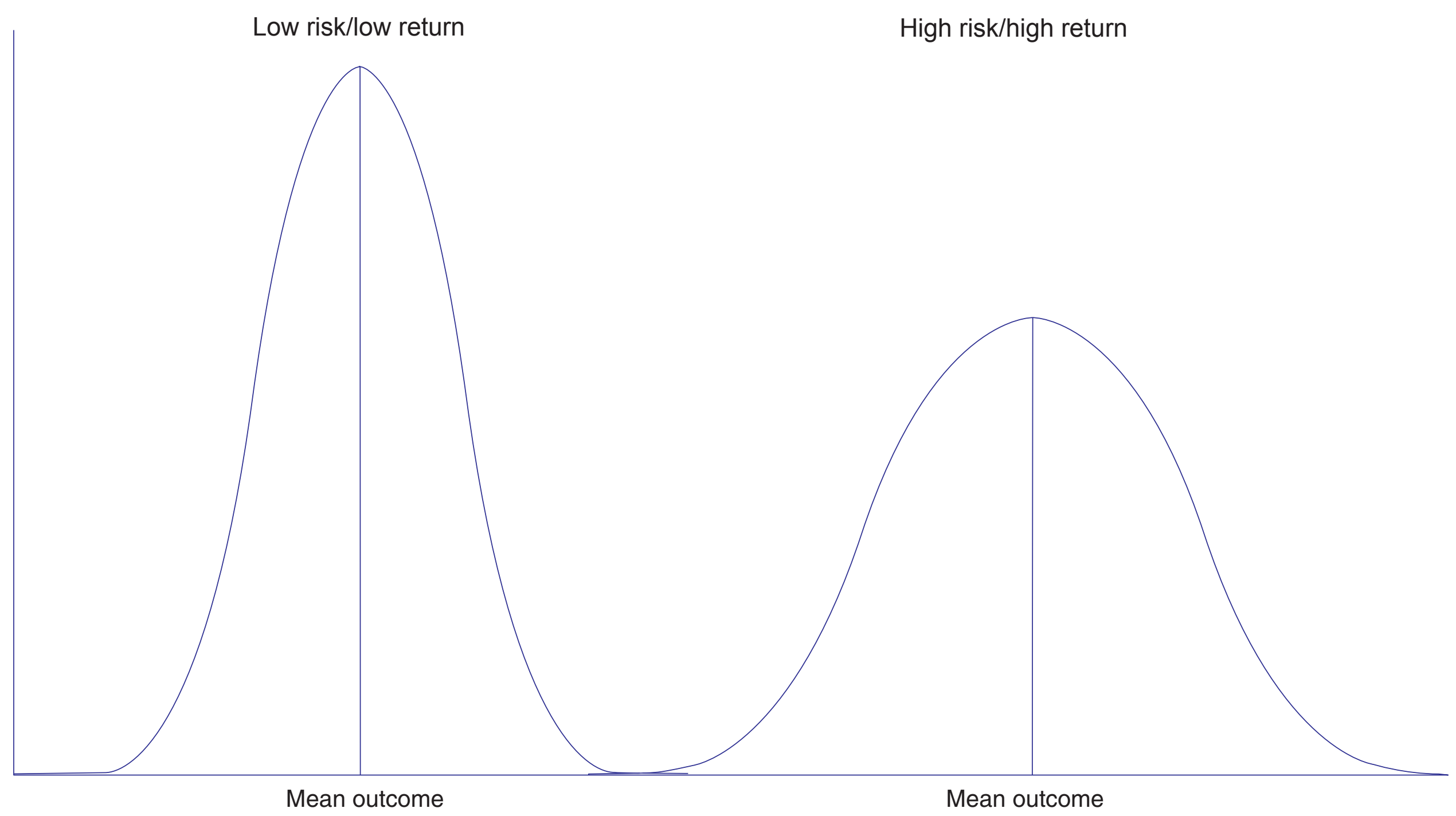


Figure 2a.

Standardized unemployment rates in OECD countries
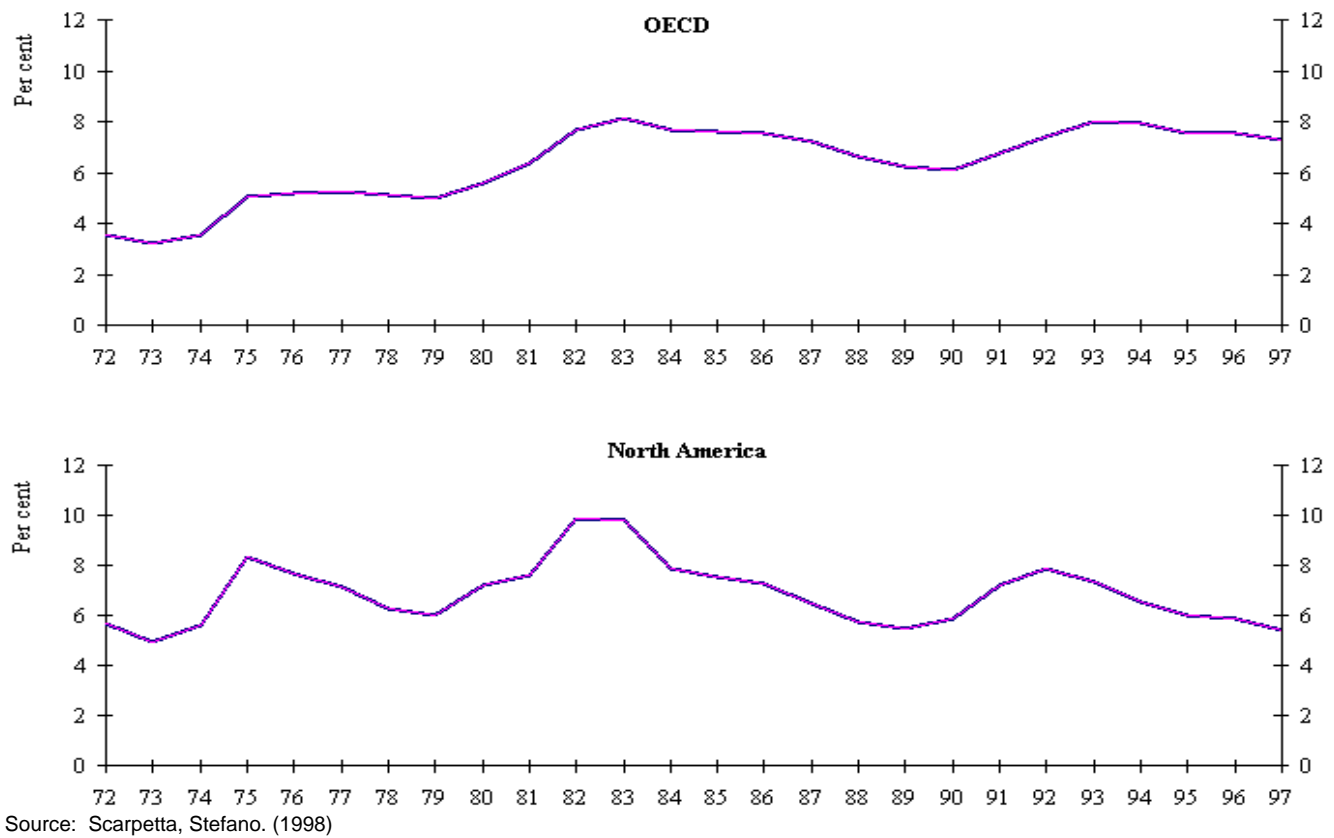
Figure $2 b$
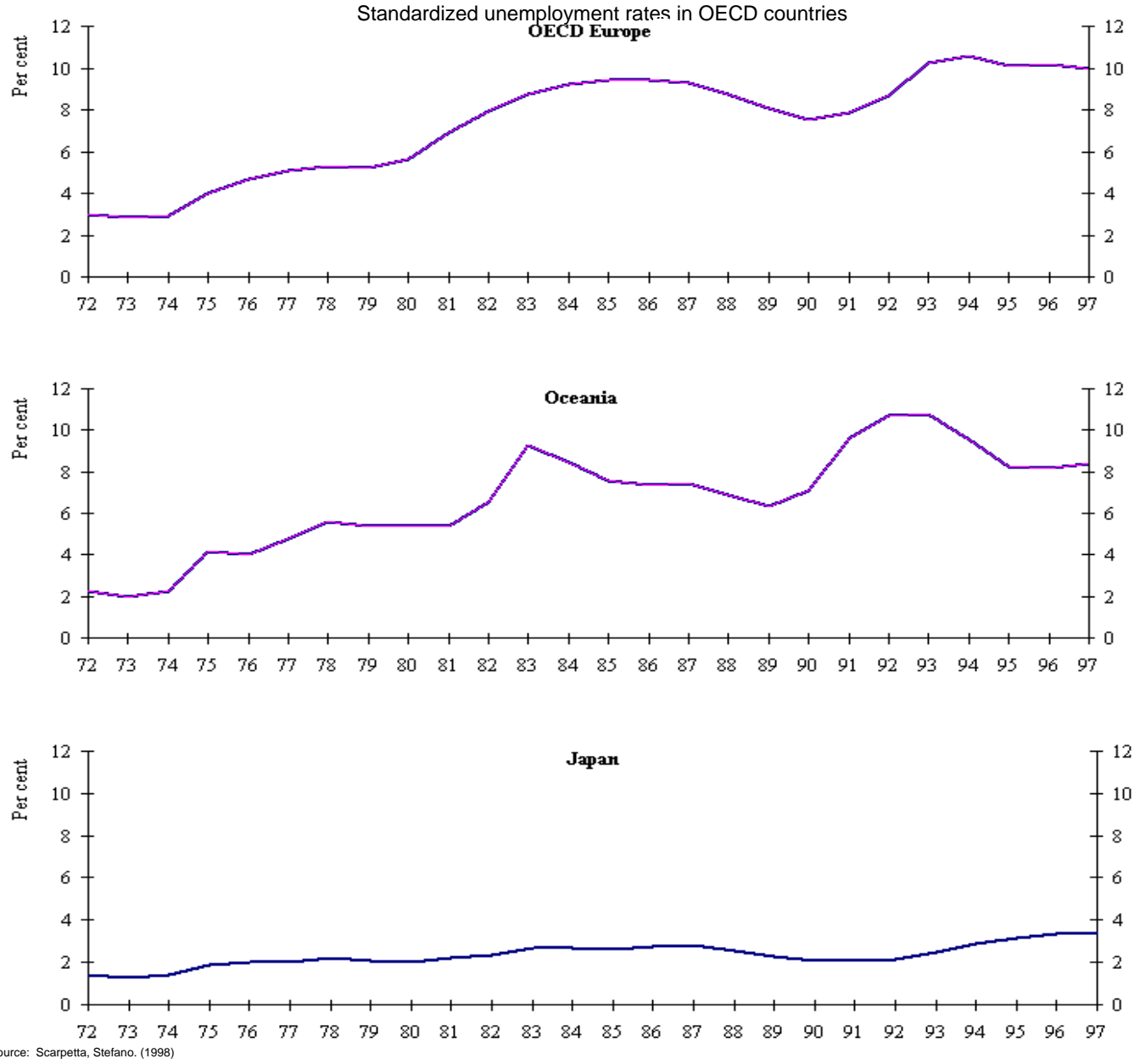


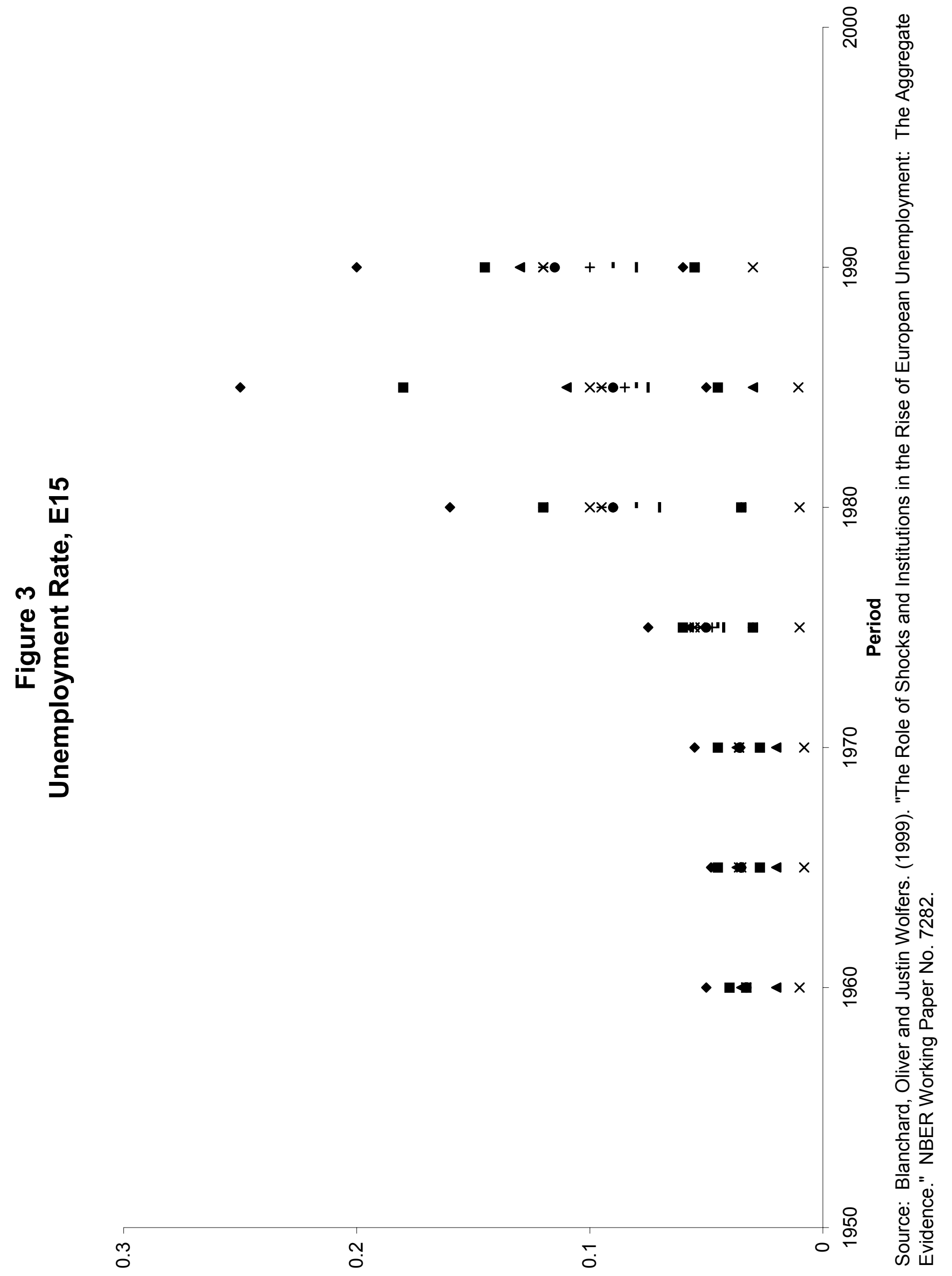


Figure 4

Long-term Unemployment as a Percentage of Total Unemployment ${ }^{\text {a) }} 1999$

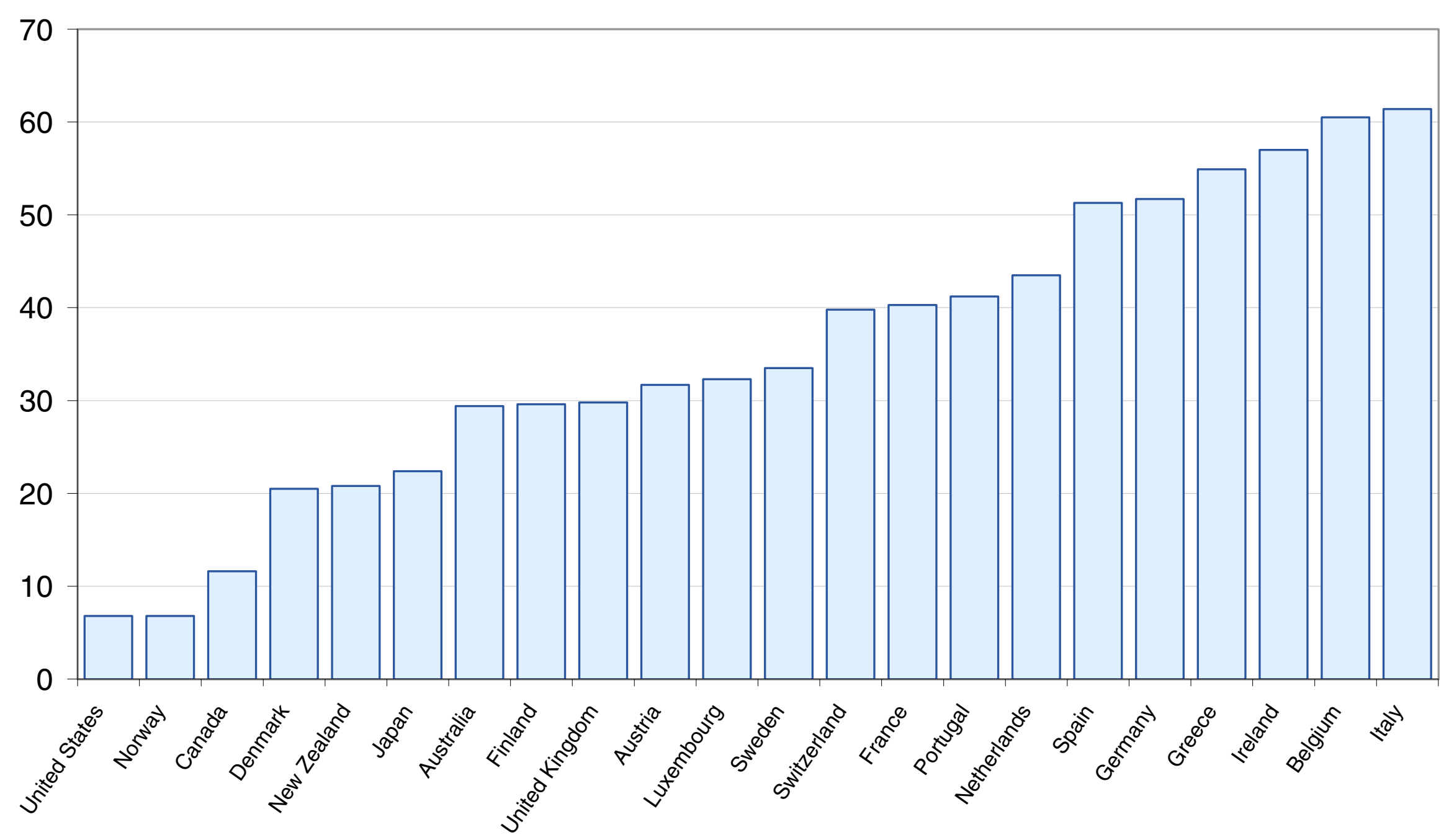

a) Unemployment of 12 months and over. 
Figure 5

\section{Youth Unemployment ${ }^{\text {a) }} 1999$}

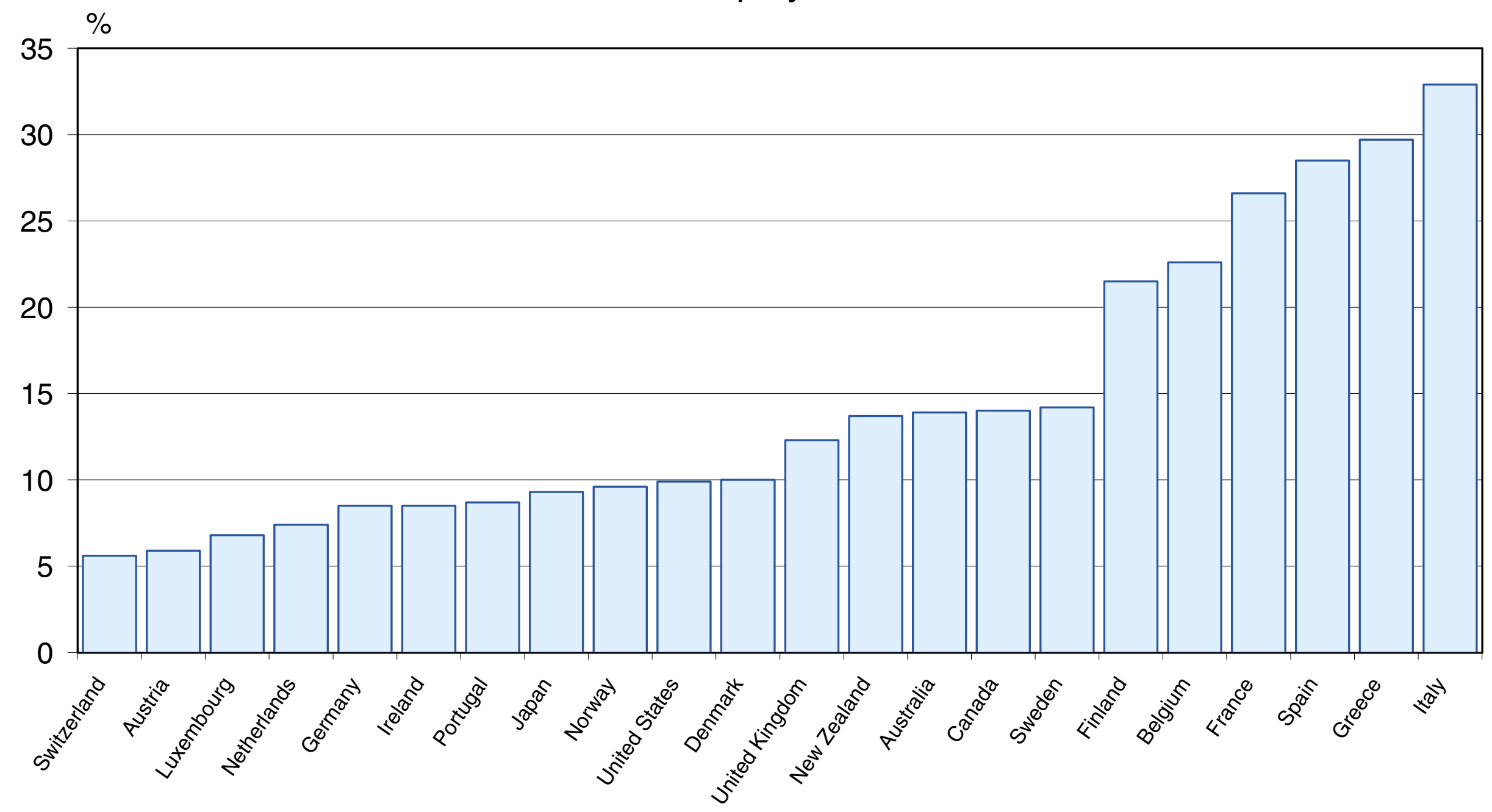

a) Ratio refers to unemployed persons aged 15 to 24 years divided by the labour force of the same age group. 
Figure 6

\section{Structural and cyclical components of unemployment rates}

Per cent of total labour force

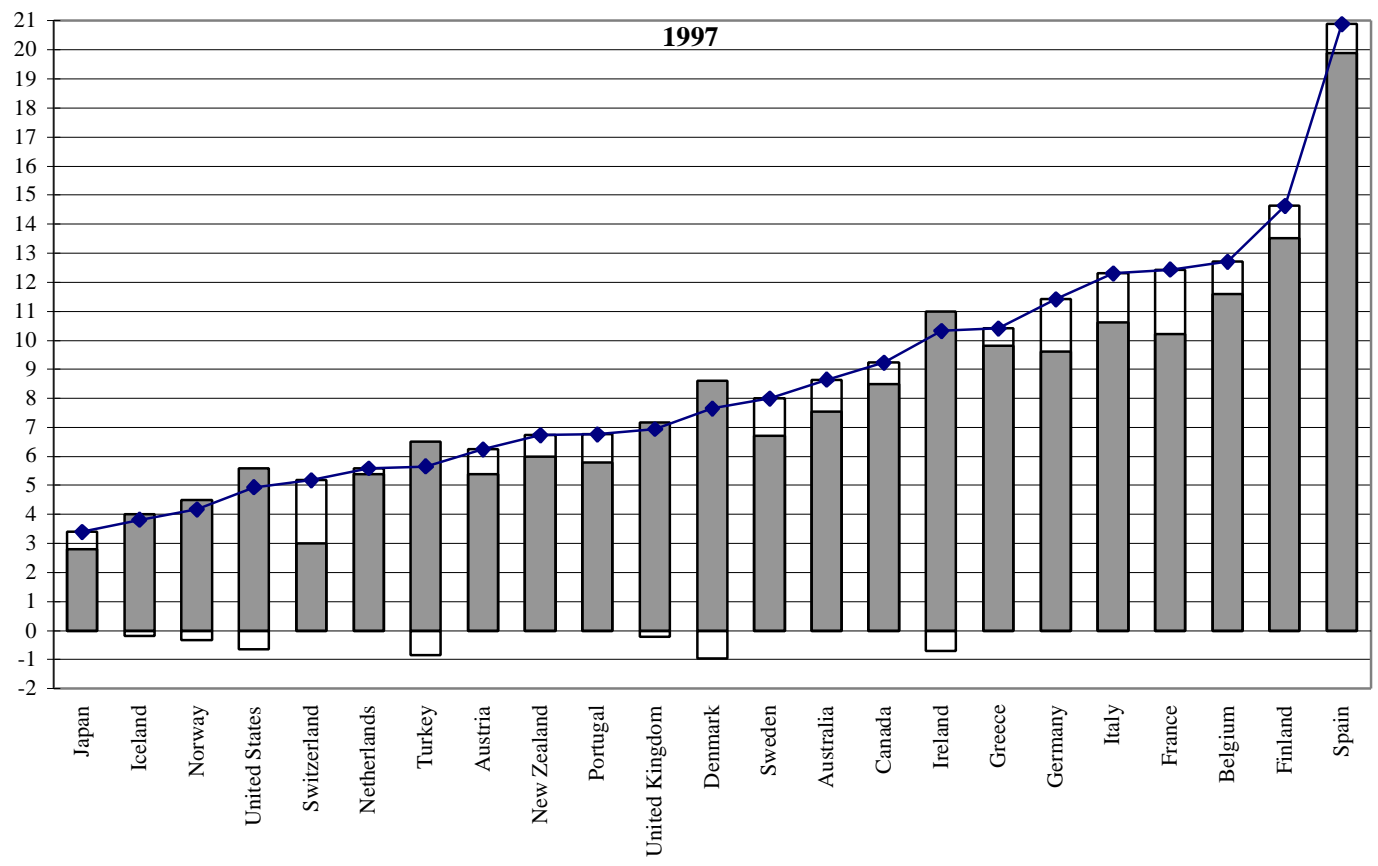

$\square$ Structural component $\square$ Cyclical component $\longrightarrow$ Unemployment rate

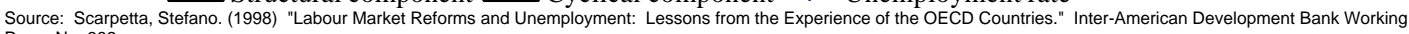
Paper No. 382 


\section{Low \\ (P10) \\ Length of bars represents the gap between high and low income individuals}

Finland 1991

Sweden I992

Belgium 1982

Norway I99I

Denmark 1992

Austria $1987^{\circ}$

Luxembourg 1985

Germany I.\$84

The Netherlands 1991

Italy 1991

Switzerland 1982

France 1984

Canada 199].

Spain 1990

Israel I९९2

Jreland 1987

Australia 1989/90

United Kingdom I૭9I

United States I99I

Table 1

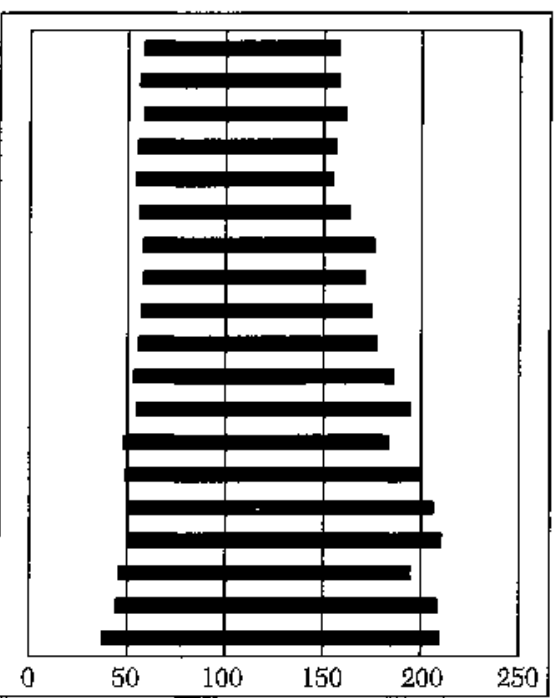

Highe High to Lowd

(P9)0)

158

159

163

158

155

163

I74

I.71

173

176

I85

193

183

198

205

209

I93

206

208

180
2.74
2.78
2.79
2.80
2.86
2.89
2.95
3.01
3.05
3.14
3.43
3.48
3.90
4.02
4.12
4.23
4.30
4.67
5.78

3.52
Gini

Coefficiente

0.227

0.229

0.230

0.230

0.239

0.227

0.238

0.249

0.268

0.255

0.311

0.294

0.285

0.306

0.305

0.328

0.308

0.335

0.350

0.274

53

Comparisons of Levels of Income Inequality: The Gap between Low and High Income Individuals (numbers given are percent of median in each nation and Gini coefficient)

Source: Gottschalk, Peter and Timothy M. Sneeding. (1997). "Cross-National Comparisons of Earnings and Income Inequality." Journal of Economic Literature. 34(2): 633-687. 
Figure 7

Strictness of Employment Protection ${ }^{\text {a) }}$

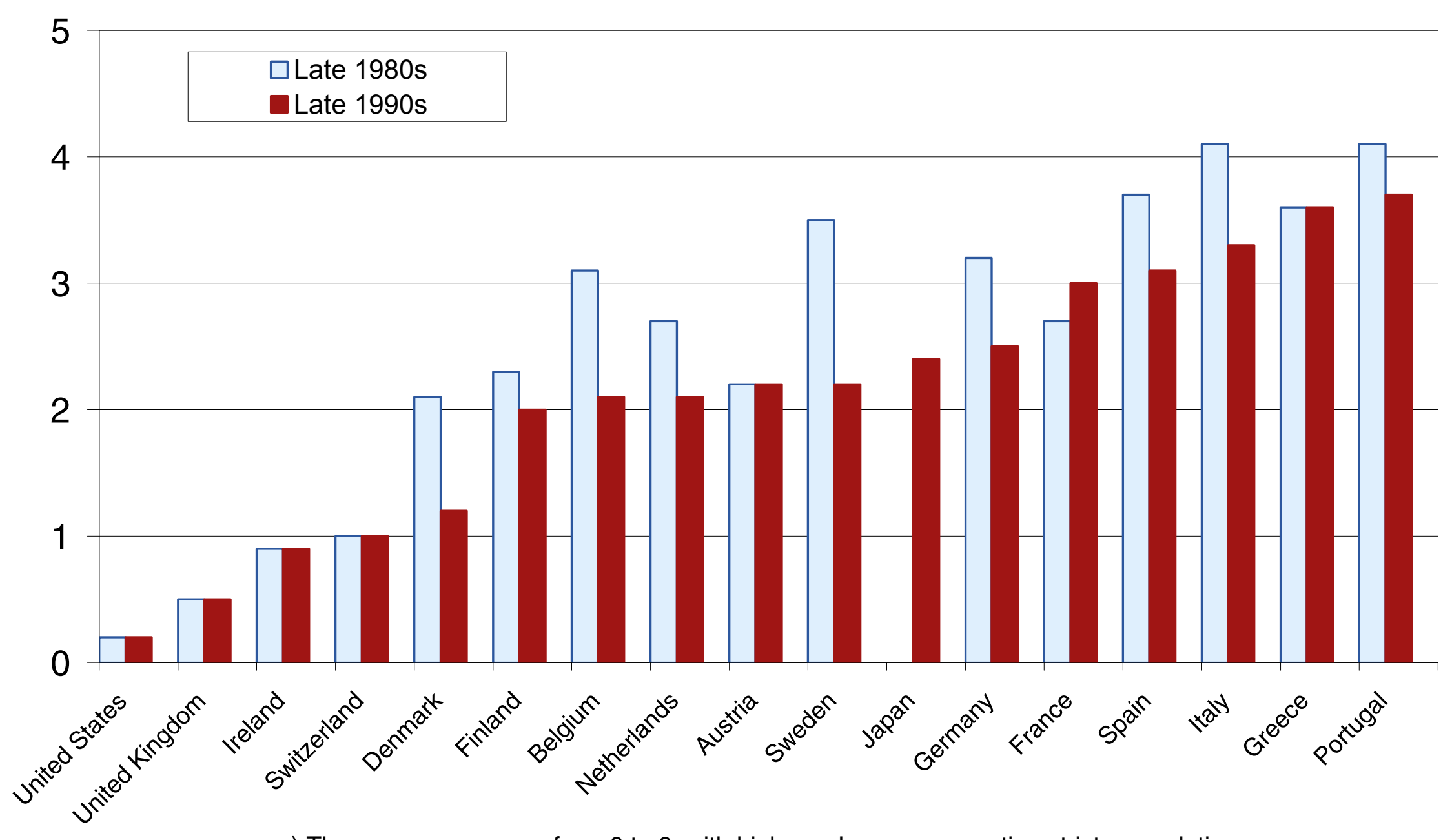

a) The scores can range from 0 to 6 , with higher values respresenting stricter regulation 
Figure 8 Percent of Employees Whose Wages Are Set by Collective Bargaining Contracts: 1980 and 1995

Unionized Workers As a Share of

Nonfarm Labor Force: 1995

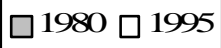

16

24

30

38

34

27

76

32

58

19

35

26

39

91

50

54

29

34

9

81

42

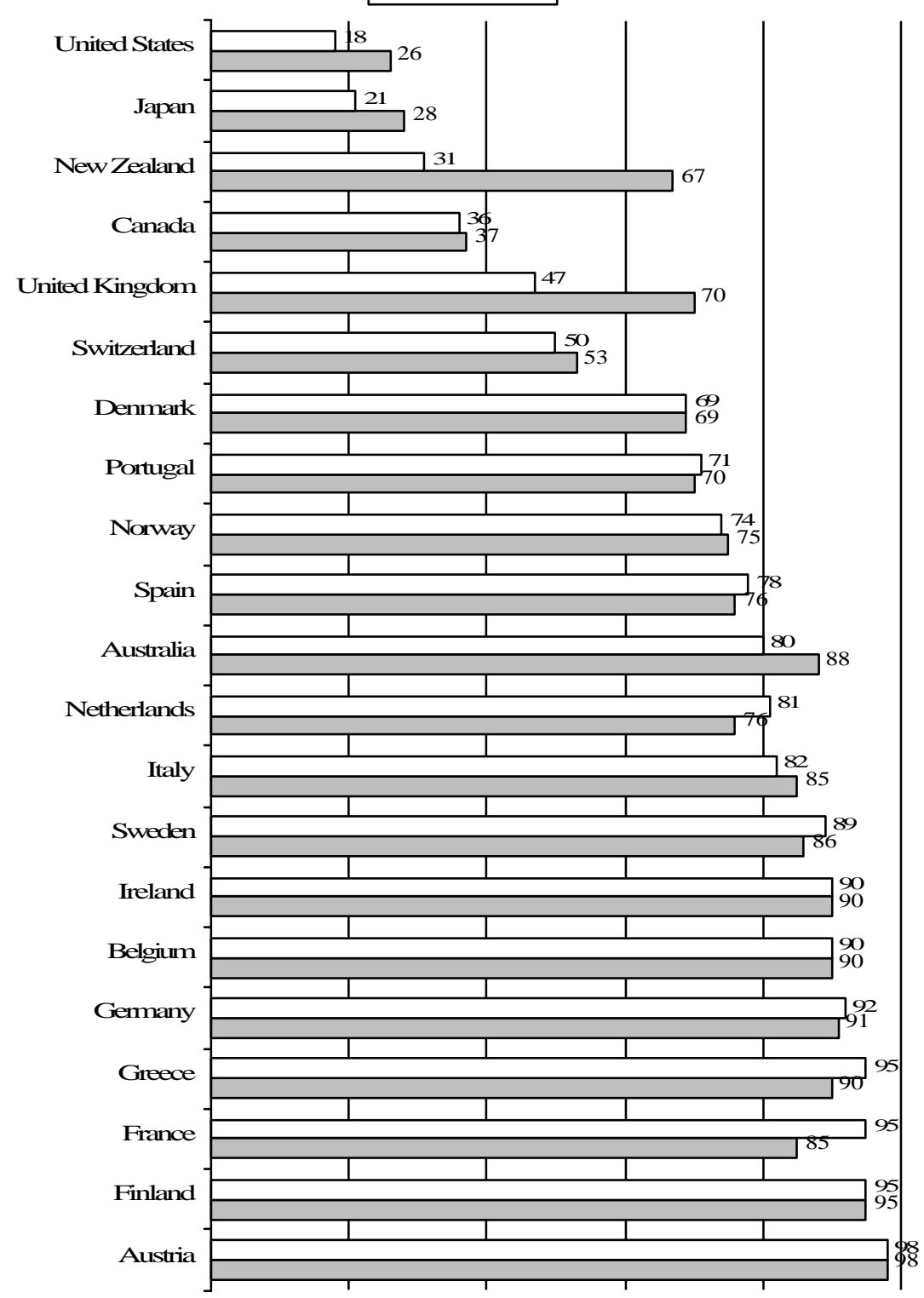

Source: OECD, Employment Outlook, July 1994 (Table 5.7), OECD Employment Outlook, July 1997 (Table 3.3), and OECD, Country Surveys (various years), 
Figure 9 The Net Initial Replacement Rate for an Unemployed Married Worker with Two Children: 1995

Net Replacement Rate (\% of Income)

(Including Housing Benefits)

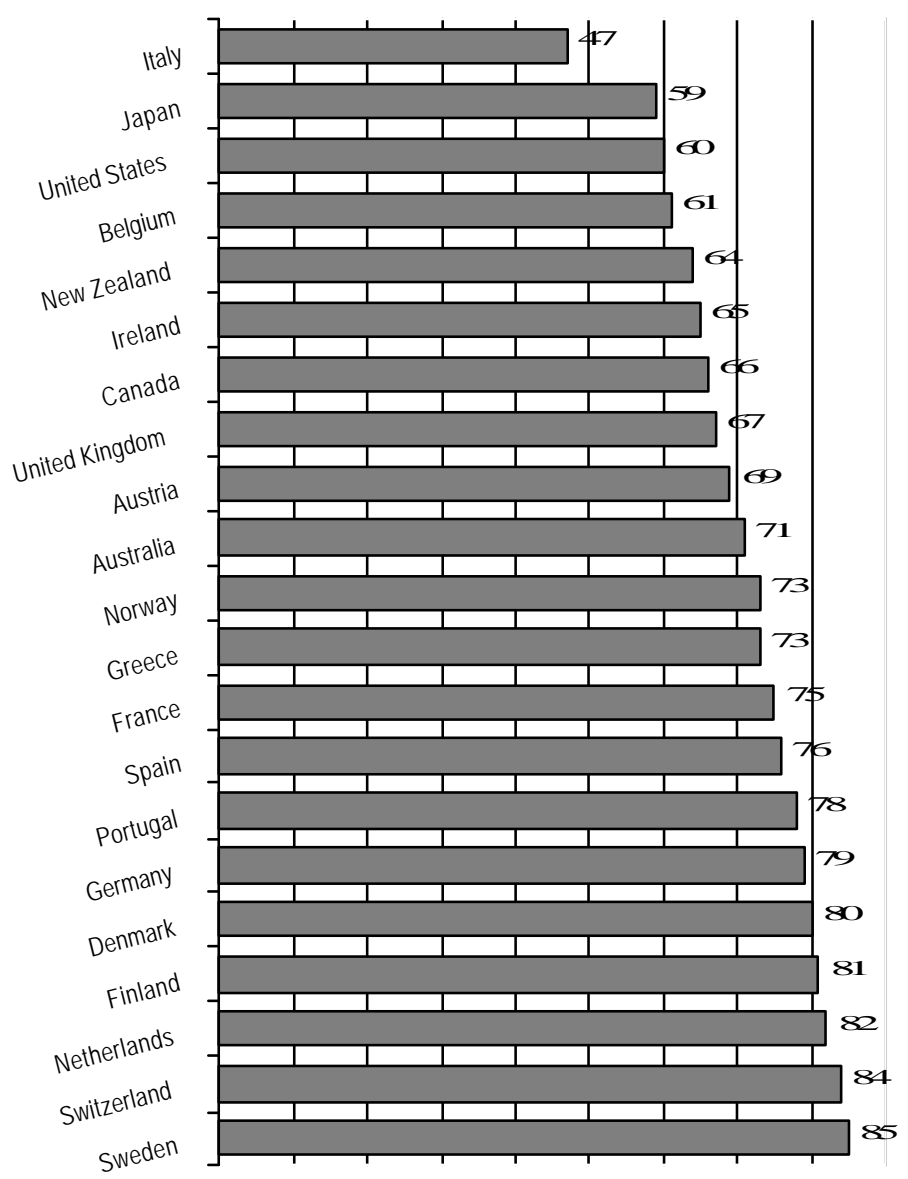

Source: OECD, Job Strategy: Making Working Pay, 1997 (Table 9) and OECD, Database on Taxation and Benefit Entitlements. These data are for a 40-yearold worker (with spouse and two children) employed continuously since age 18. 


\section{Table 2 Tax wedge and social security contributions}

(in percent of gross wages). (Source: Scarpetta, S., 1998)

\begin{tabular}{|c|c|c|c|c|c|}
\hline \multirow[b]{3}{*}{ Australia } & \multicolumn{2}{|c|}{ Total tax wedge } & \multicolumn{3}{|c|}{$\begin{array}{c}\text { Employers' social security } \\
\text { contribution rate }\end{array}$} \\
\hline & 1985 & 1994 & 1985 & & 1994 \\
\hline & 22,9 & 23,5 & 0,0 & $\overline{0,0}$ & \\
\hline Austria & 40,3 & 39,7 & 18,6 & 19,1 & \\
\hline Belgium & 54,2 & 53,5 & 28,8 & 25,8 & \\
\hline Canada & 26,9 & 31,4 & 4,7 & 6,2 & \\
\hline Denmark & 47,8 & 45,2 & 2,8 & 0,0 & \\
\hline Finland & 38,0 & 39,4 & 5,7 & 3,6 & \\
\hline France & 43,4 & 43,6 & 27,5 & 26,2 & \\
\hline Germany & 44,5 & 48,3 & 14,5 & 16,3 & \\
\hline Greece & 31,4 & .. & 17,9 & 21,6 & \\
\hline Iceland & 16,5 & 22,9 & 2,1 & 2,8 & \\
\hline Ireland & 42,4 & 38,4 & 10,9 & 10,9 & \\
\hline Italy & 50,0 & 49,9 & 29,9 & 31,5 & \\
\hline Japan & 21,6 & 21,6 & 6,8 & 7,0 & \\
\hline Luxembourg & 38,4 & 35,1 & 13,3 & 13,0 & \\
\hline Mexico & .. & 26,5 & 15,2 & 16,2 & \\
\hline Netherlands & 49,9 & 45,6 & 19,2 & 7,3 & \\
\hline New Zealand & 27,9 & 24,3 & 0,0 & 0,0 & \\
\hline Norway & 41,8 & 36,9 & 13,5 & 11,3 & \\
\hline Portugal & 30,7 & 34,3 & 16,7 & 19,7 & \\
\hline Spain & 36,6 & 38,8 & 23,8 & 24,0 & \\
\hline Sweden & 50,9 & 46,8 & 24,0 & 23,2 & \\
\hline Switzerland & 28,8 & 28,7 & 9,4 & 9,3 & \\
\hline Turkey & 37,0 & 35,7 & 8,3 & 6,7 & \\
\hline United Kingdom & 37,8 & 33,3 & 9,5 & 9,3 & \\
\hline United States & 33,6 & 31,2 & 6,6 & 7,1 & \\
\hline
\end{tabular}

1. Total tax wedges include income taxes, employer and employee social security contributions, but not indirect taxes. Tax rates refer to one earner without dependents and take into account standard tax relief.

Source: OECD, Tax/Benefit Position of Production Workers (various issues). 


\section{Table 3.}

Minimum to Average Wage in Latin America and the Industrialized Countries

\begin{tabular}{|c|c|c|c|}
\hline "Bolivia(1995) & 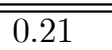 & $\overline{\text { Columbia } 95 \square}$ & 0.54 \\
\hline Brazil (1995) & $0.24 \square$ & Costa $[$ Rica $95 \square$ & 0.54 \\
\hline Argentinal $95 \square$ & $0.26 \square$ & Denmark $94 \square$ & 0.54 \\
\hline Chile 94 & 0.30 & Germany 91 & 0.55 \\
\hline Spain & 0.32 & Ireland 93 & 0.55 \\
\hline Mexico 94 & 0.36 & Netherlands & 0.55 \\
\hline Peru 96 & 0.36 & Luxembourg & 0.56 \\
\hline USA 93 & 0.39 & Belgium 92 & 0.60 \\
\hline UK 93 & 0.40 & Honduras 96 & 0.61 \\
\hline Panama 95 & 0.43 & Austria 93 & 0.62 \\
\hline Portugal & 0.45 & Greece 95 & 0.62 \\
\hline France & 0.50 & Paraguay 95 & 0.64 \\
\hline Finland 93 & 0.52 & El Salvador 95 & 0.69 \\
\hline Sweden & 0.52 & Italy 91 & 0.71 \\
\hline Switzerkand & 0.52 & Venezuela & 0.88 \\
\hline
\end{tabular}

Source: LAC countries; authors' calculations based on household surveys. Industrial countries; Dolado et al. (1996) 
Figure 10 Unemployment Response to GDP Growth

\section{Change in unemployment rate}

\begin{tabular}{lllllllllll}
-1.6 & -1.4 & -1.2 & -1 & -0.8 & -0.6 & -0.4 & -0.2 & 0 & 0.2 & 0.4 \\
\hline
\end{tabular}

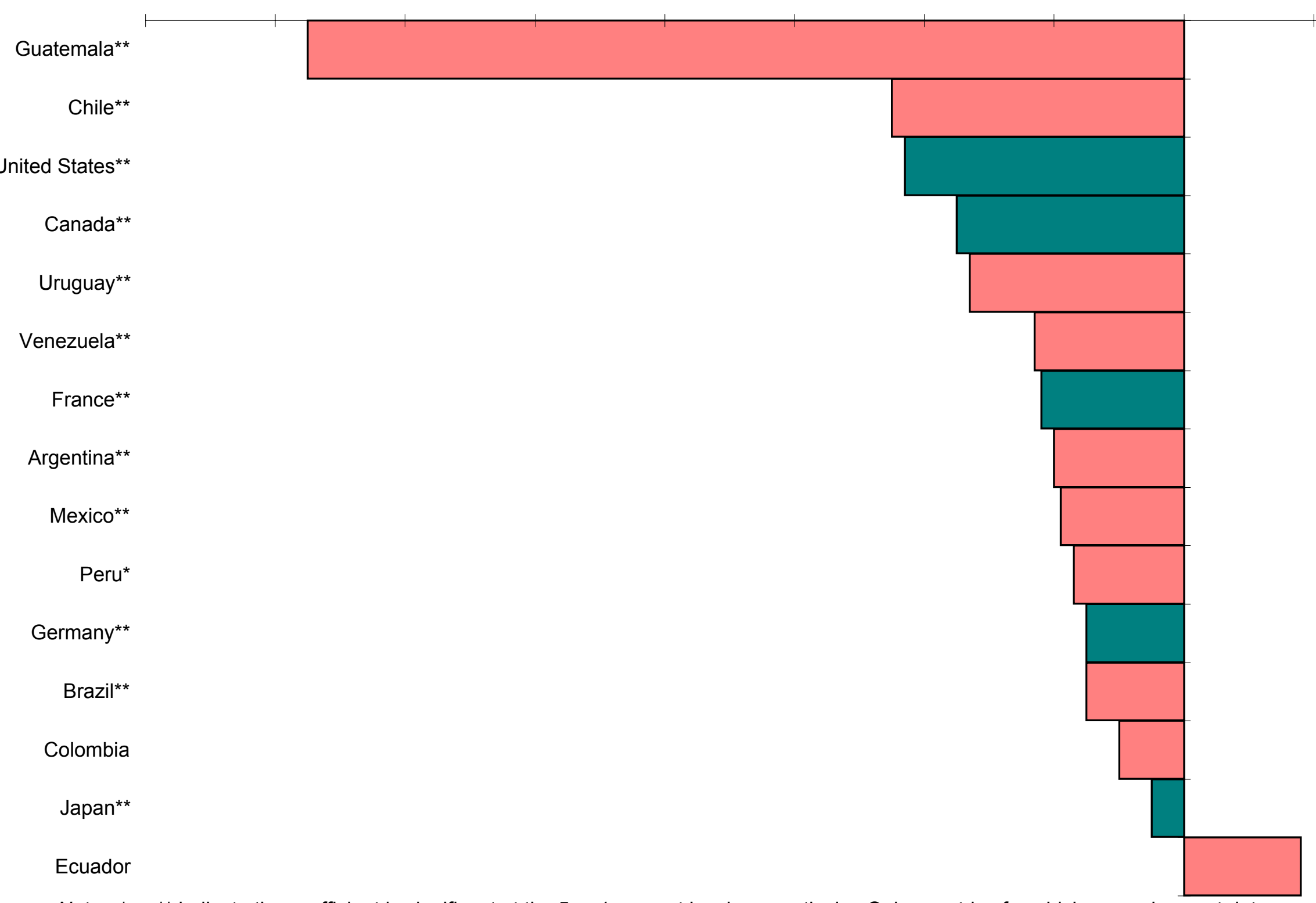

Note: * or ${ }^{* *}$ indicate the coefficient is significant at the 5 or 1 percent level, respectively. Only countries for which unemployment data is available for at least 10 years are included.

Source: Economic and Social Progress in Latin America: 1996 Report. Special Section: Making Social Services Work. The InterAmerican Development Bank. Washington, D.C.: Johns Hopkins University Press. 1996. 
Figure 11 Overall Employment and Labor Market Regulation

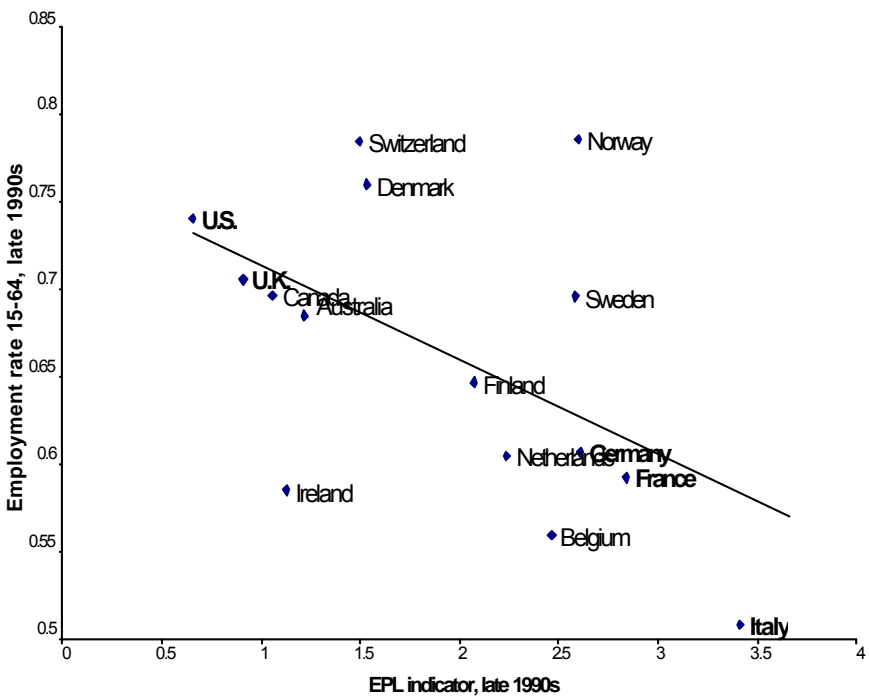

Source: Bertola, Guiseppe. (2001) "Aggregate and Disaggregate Aspects of Employment and Unemployment." Central Bank of Colombia Conference Paper. 
Figure 12 Employment Protection Legislation and Wage Inequality

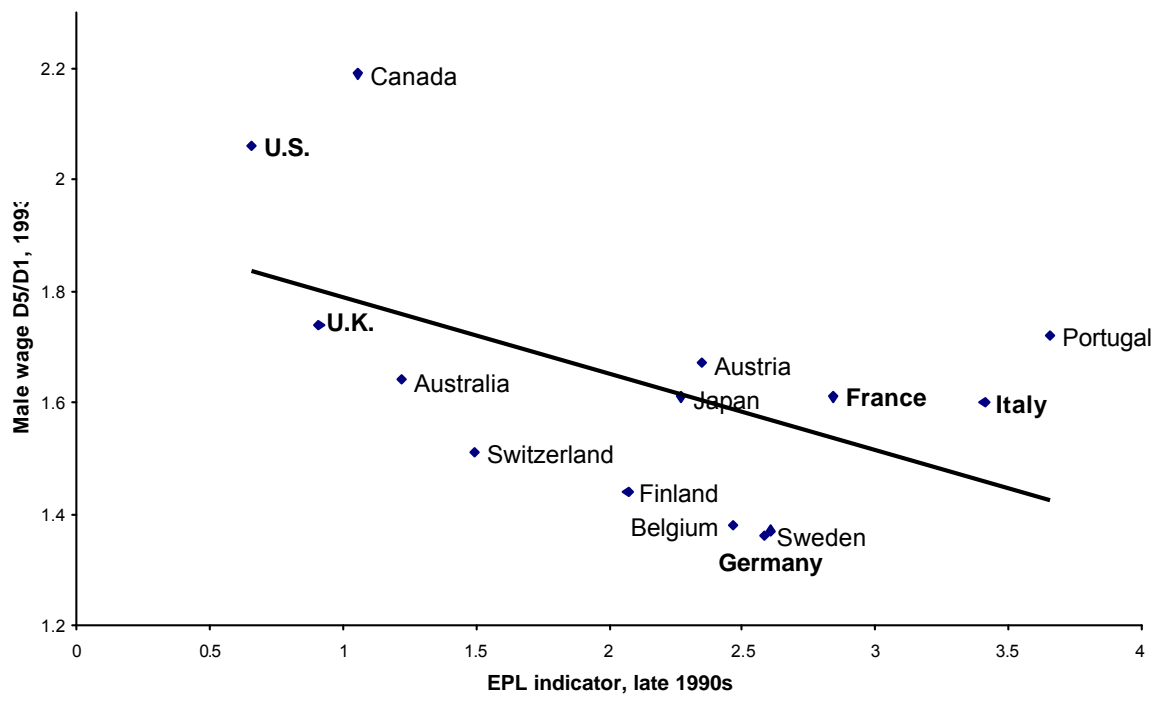

Source: Bertola, Guiseppe. (2001) "Aggregate and Disaggregate Aspects of Employment and Unemployment." Central Bank of Colombia Conference Paper. 


\section{Figure 13 Employment Protection Legislation and Tenure Length}

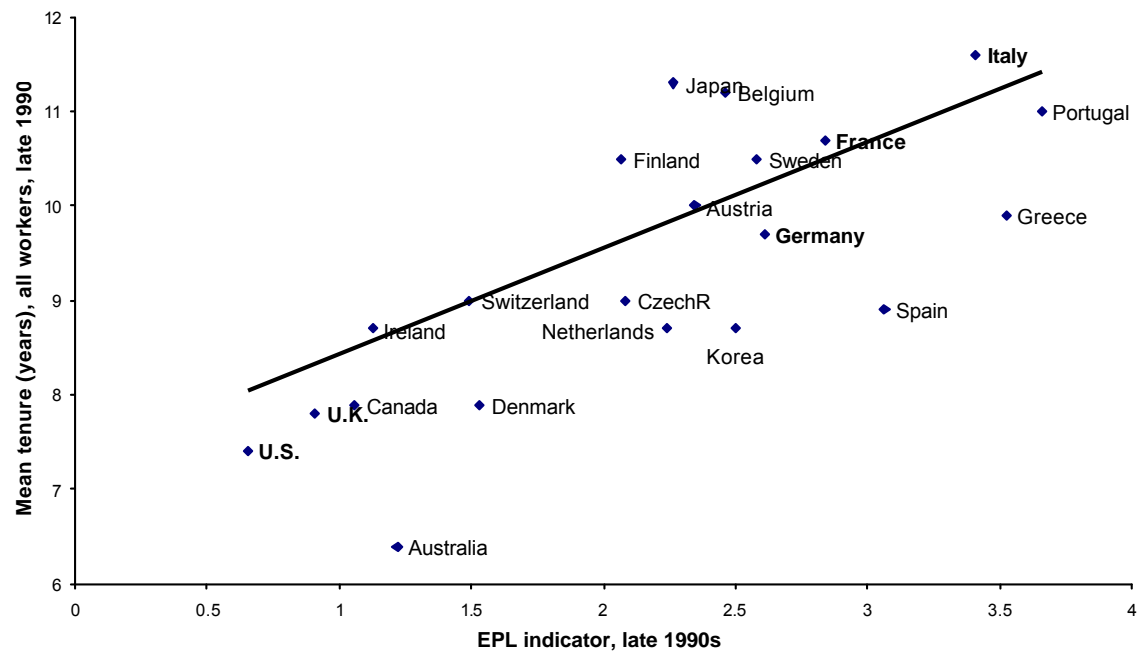

Source: Bertola, Guiseppe. (2001) "Aggregate and Disaggregate Aspects of Employment and Unemployment." Central Bank of Colombia Conference Paper. 
Figure 14 Male Adult Employment and Labor Market Regulation

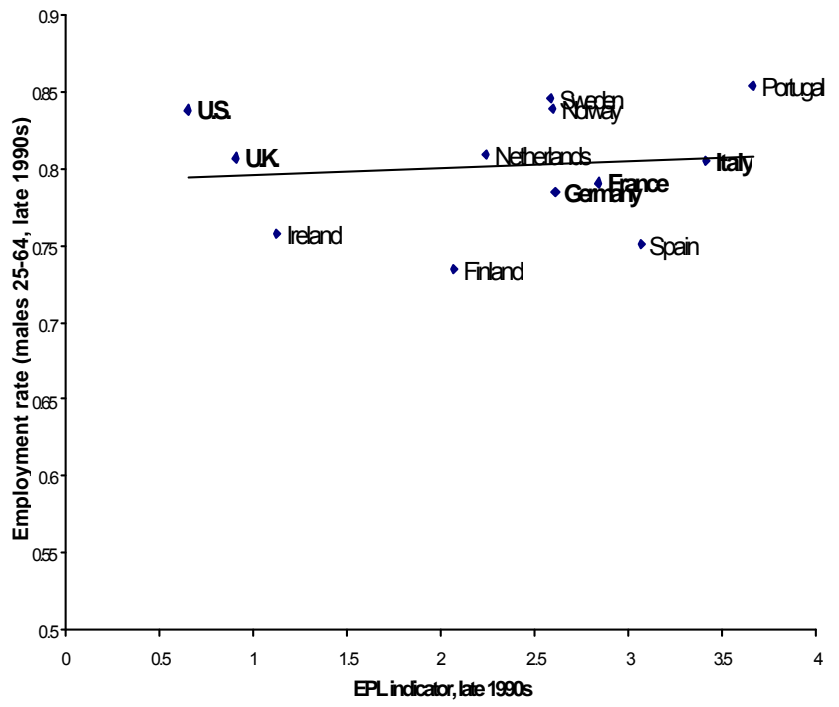

Source: Bertola, Guiseppe. (2001) "Aggregate and Disaggregate Aspects of Employment and Unemployment." Central Bank of Colombia Conference Paper. 


\section{Figure 15 Overall indicator of product market regulation ${ }^{1}$}

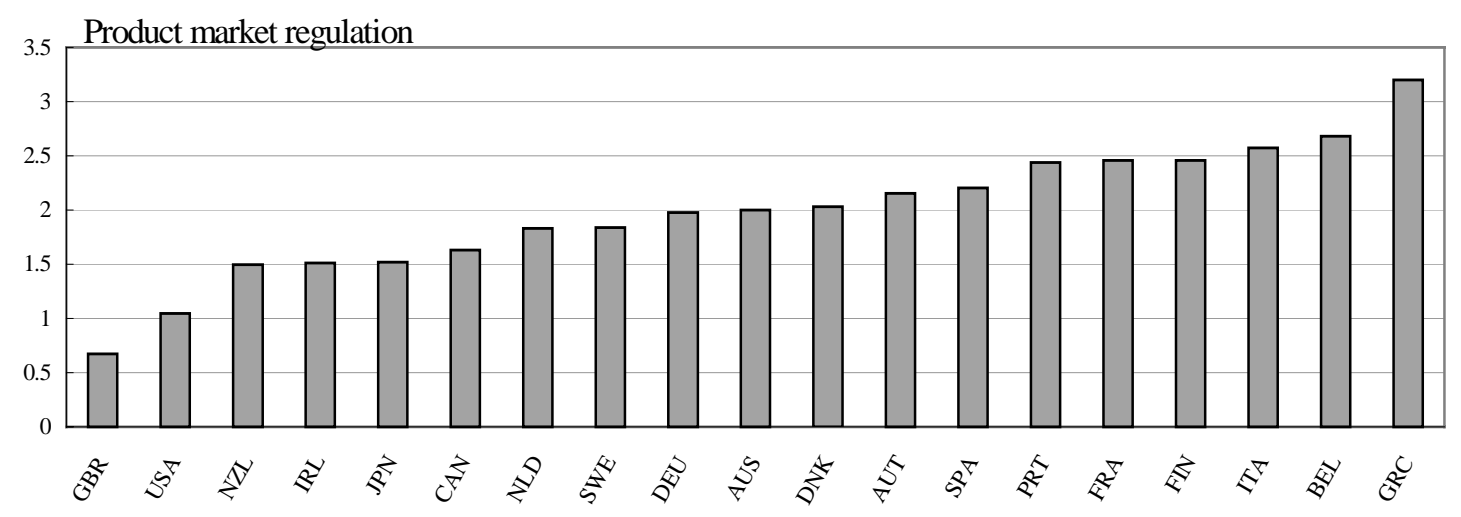

1. Factor analysis applied to summary indicators of state control, barriers to entrepreneurial activity and barriers to trade and investment. 
Employment protection legislation

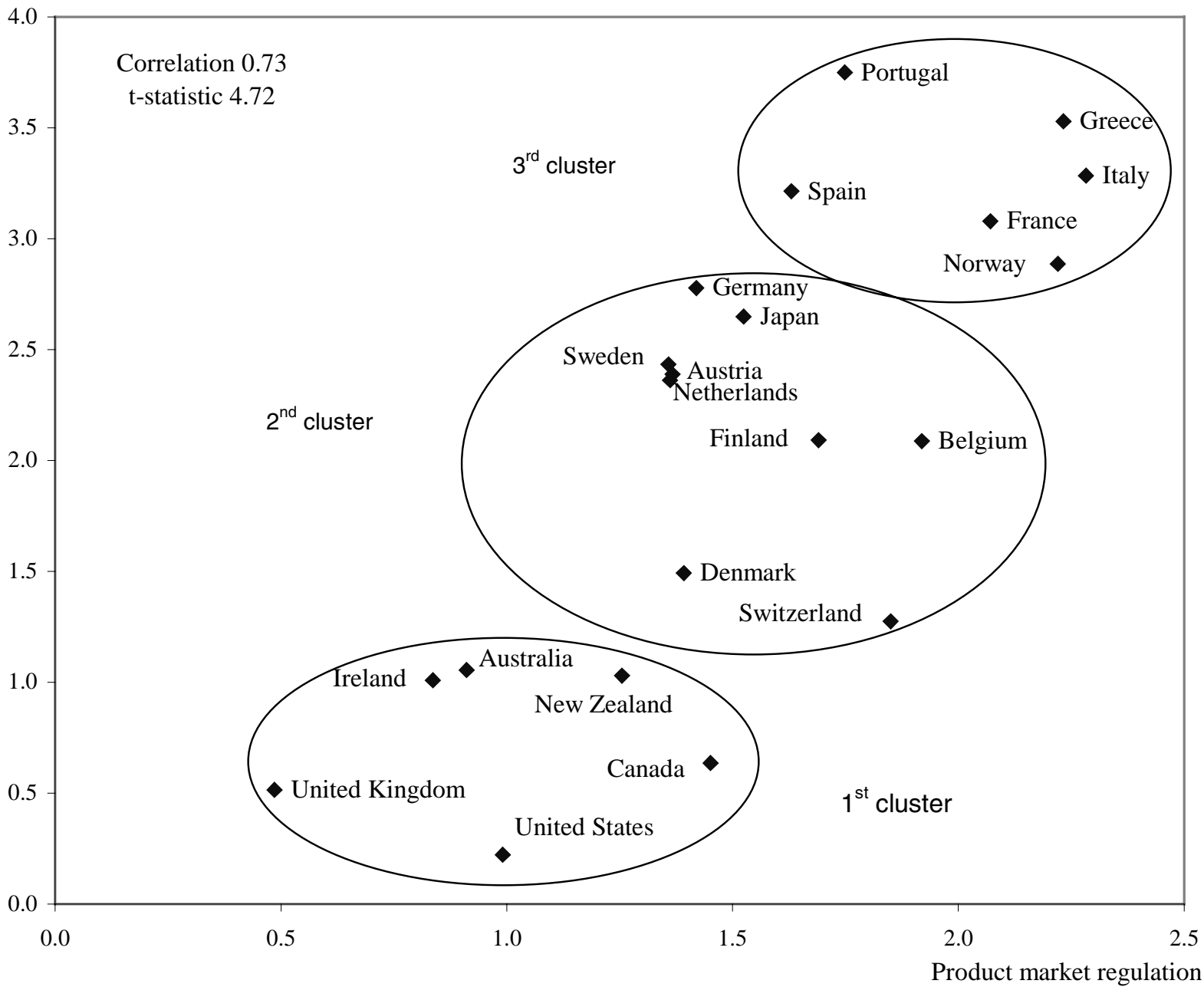

1. The scale of indicators is $0-6$ from least to most restrictive

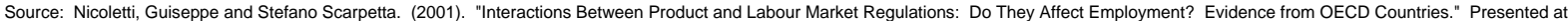
Banco de Portugal Conference on "Labour Market Institutions and Economic Outcomes", June 3-4, 2001. 
Countries (Source: Freeeman, R.B, 2001)

\begin{tabular}{|c|c|c|c|c|c|c|}
\hline & \multicolumn{3}{|c|}{ Business Formation } & \multicolumn{3}{|c|}{ Protection of Investors (higher= better) } \\
\hline & Procedures & Days to get & $\bar{C}$ Cost/GDP & Rule of Law & Anti-Director & Creditor \\
\hline & equired & Approval & Per Capita & & Rights & Rights \\
\hline Australia & 3 & 3 & .0209 & 10 & 4 & 1 \\
\hline Austria & 12 & 154 & .4545 & 10 & 2 & 3 \\
\hline Belgium & 8 & 42 & .1001 & 10 & 0 & 2 \\
\hline Canada & 2 & 2 & .0140 & 10 & 4 & 1 \\
\hline Denmark & 5 & 21 & .0136 & 10 & 3 & 3 \\
\hline Finland & 4 & 32 & .0199 & 10 & 2 & 1 \\
\hline France & 16 & 66 & .1970 & 8.98 & 2 & 0 \\
\hline Germany & 7 & 90 & .0851 & 9.23 & 1 & 3 \\
\hline Greece & 13 & 53 & .4799 & 6.18 & 1 & 1 \\
\hline Ireland & 4 & 25 & .1145 & 7.80 & 3 & 1 \\
\hline Italy & 11 & 121 & .2474 & 8.33 & 0 & 2 \\
\hline Japan & 11 & 50 & .1144 & 8.98 & 3 & 2 \\
\hline Neth & 8 & 77 & .3031 & 10 & 2 & 2 \\
\hline N Zealand & 3 & 17 & .0042 & 10 & 4 & 3 \\
\hline Norway & 6 & 24 & .0249 & 10 & 3 & 2 \\
\hline Portugal & 12 & 99 & .3129 & 8.68 & 2 & 1 \\
\hline Spain & 11 & 83 & .1269 & 7.80 & 2 & 2 \\
\hline Sweden & 4 & 17 & .0254 & 10 & 2 & 2 \\
\hline Switzerland & 12 & 88 & .1336 & 10 & 1 & 1 \\
\hline United Kingdo & on 7 & 11 & .0056 & 8.57 & 4 & 4 \\
\hline United States & 4 & 7 & .0096 & 10 & 5 & 1 \\
\hline
\end{tabular}


Figure 17 Internet Usage and Employment Protection

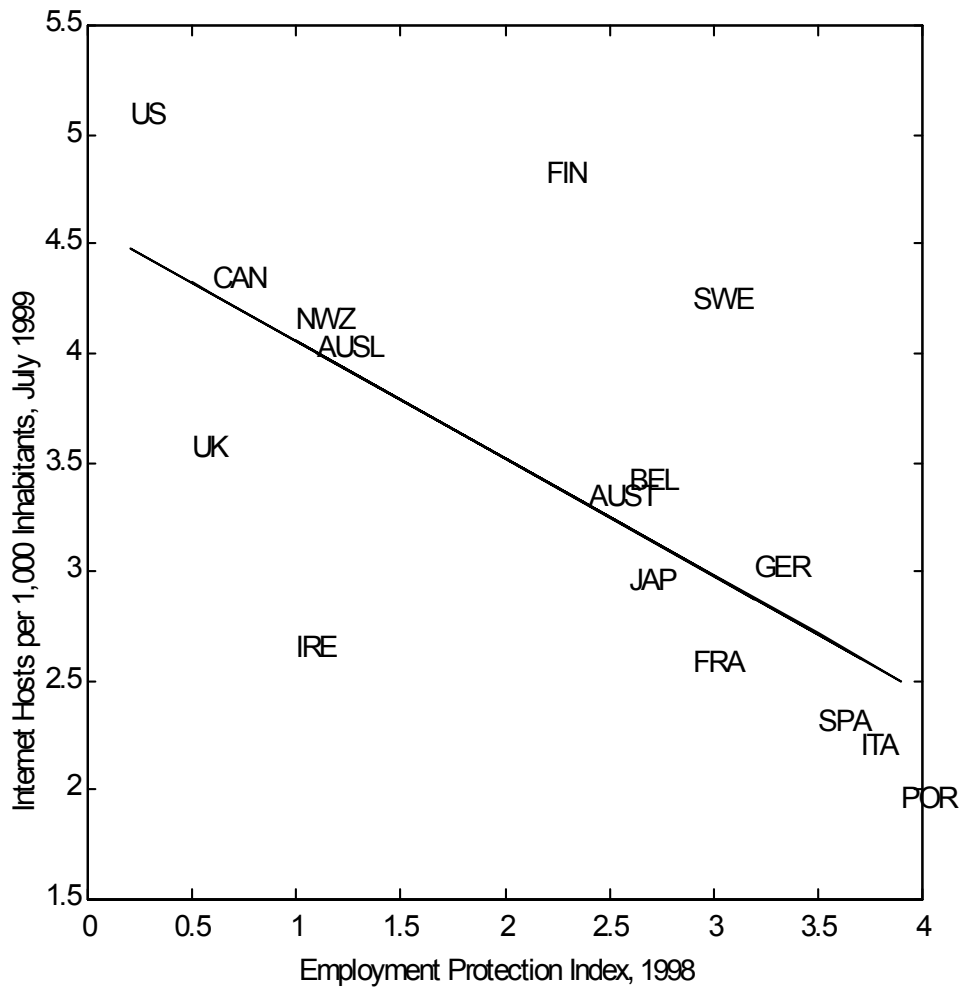

Source: Samaniego, Roberto. (2001) "Does Unemployment Protection Inhibit Technology Diffusion." Unpublished manuscript. University of Pennsylvania. 
Figure 18 Web server sites per 1000 inhabitants, July 1998 (including: com, net, org)

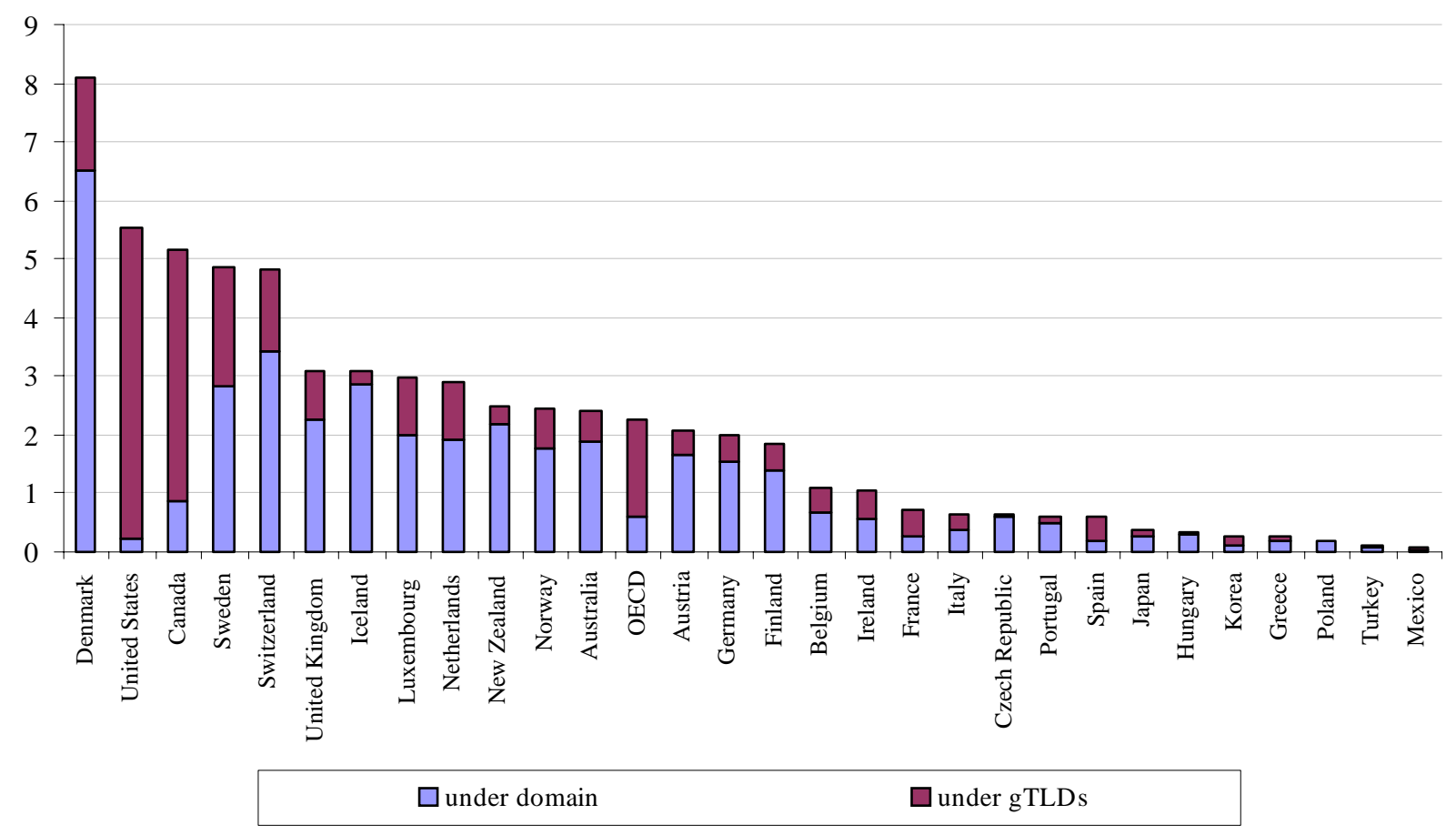


Figure 19 Foreign Direct Investment

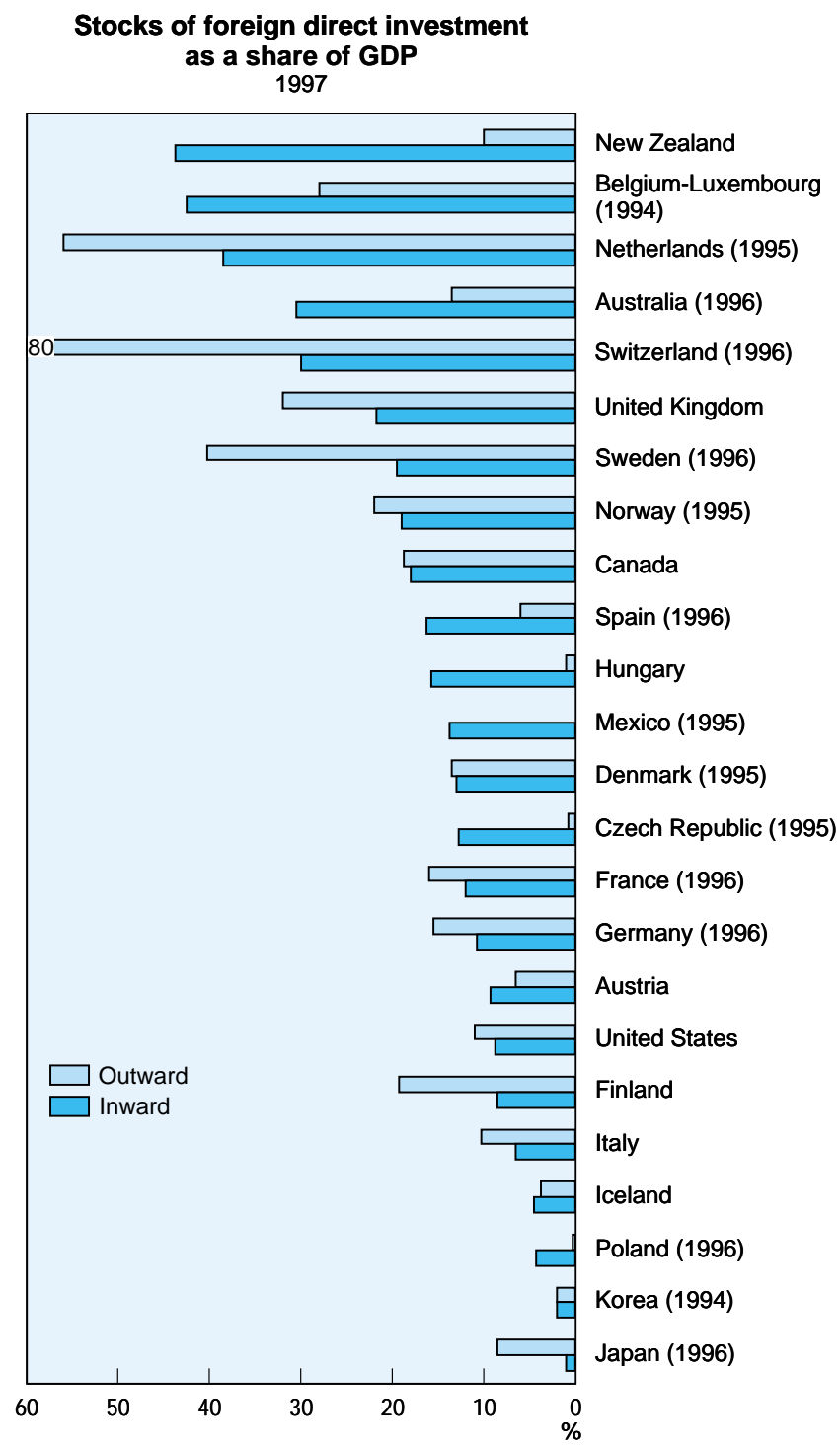

Source : OECD, International Direct Investment database and IMF, May 1999. 


\section{Figure 19 (cont.) Foreign Direct Investment}

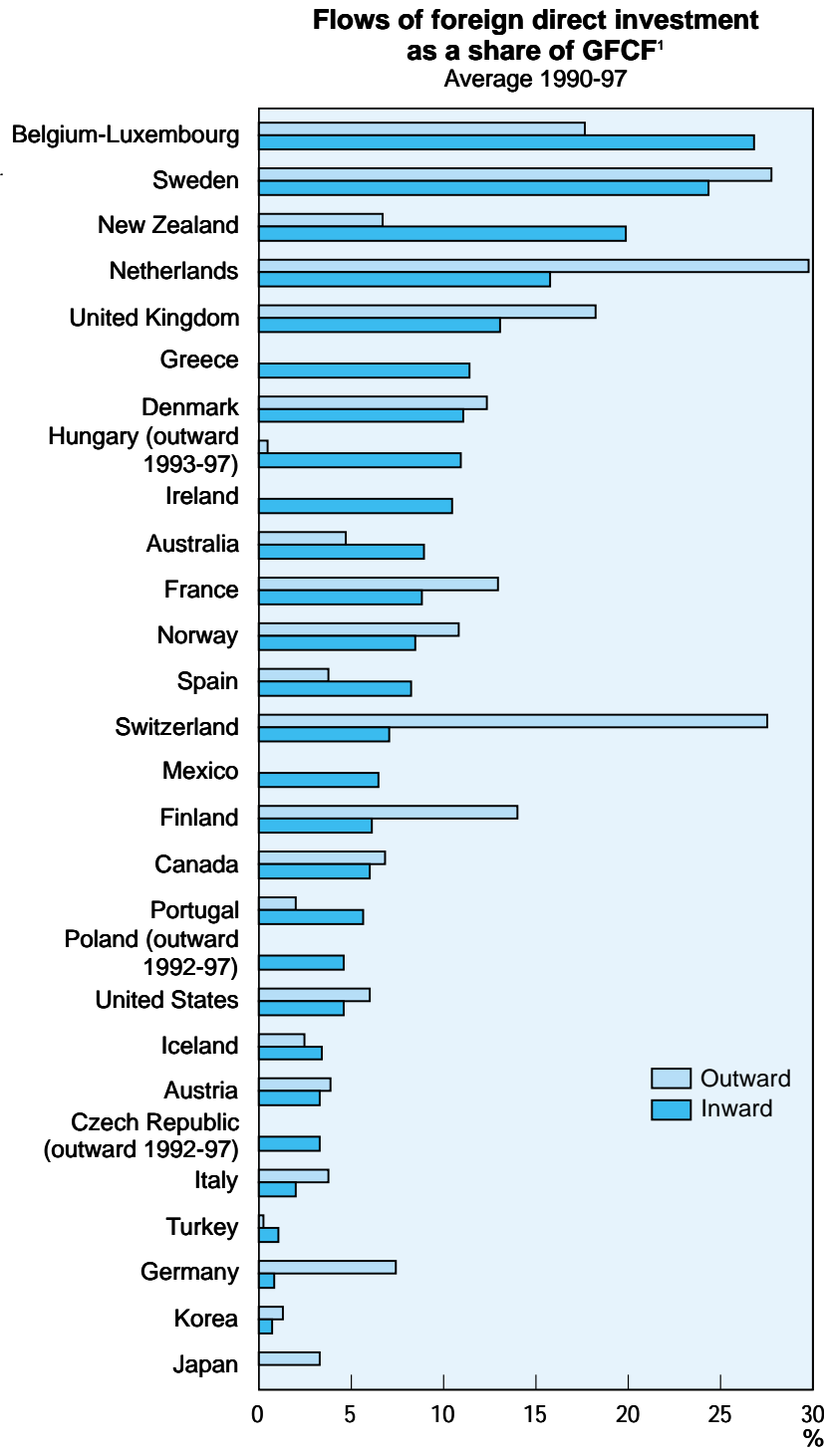

1. GFCF: Gross Fixed Capital Formation

Source: OECD, International Direct Investment database and IMF, May 1999. 


\section{Figure 20 Venture capital}
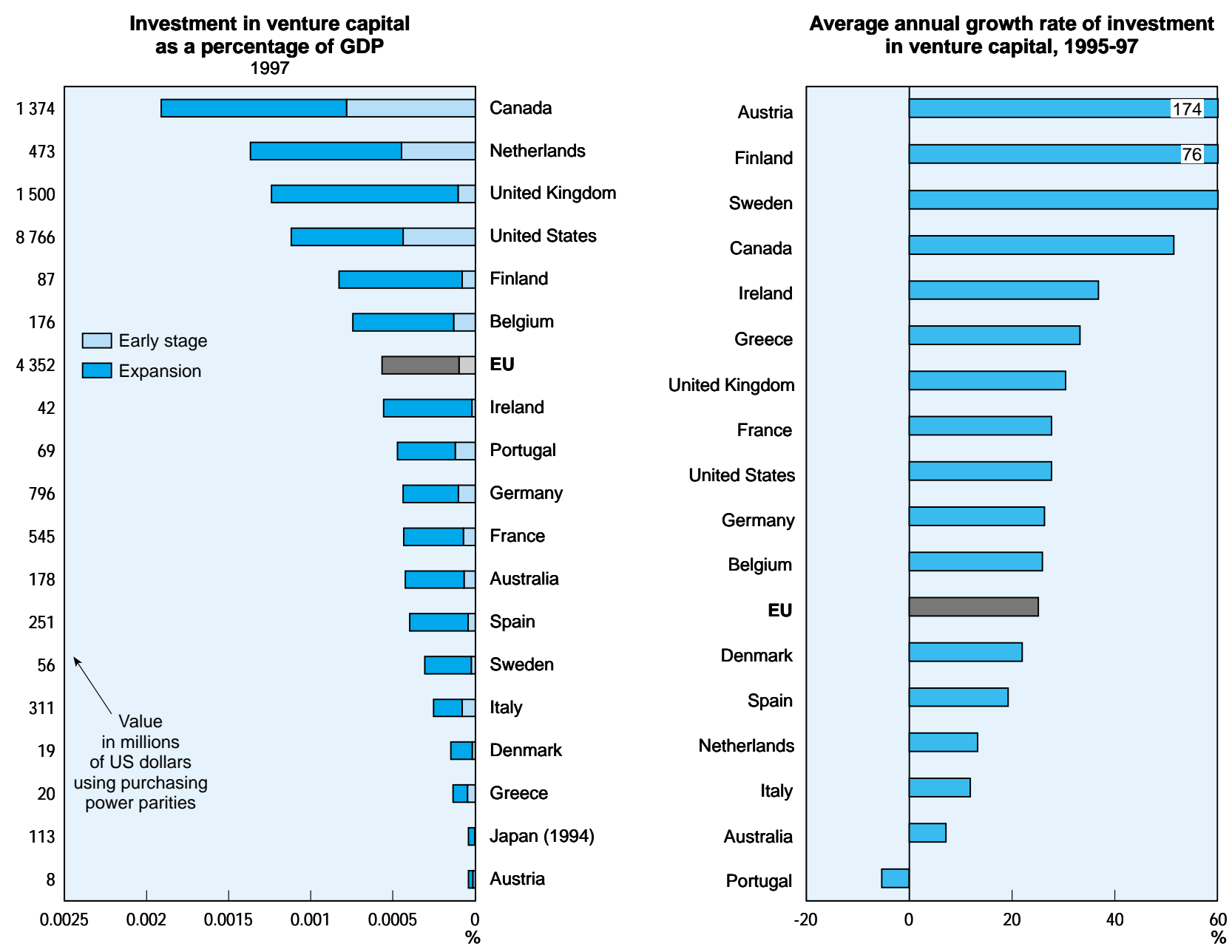

Distribution of venture capital by industry, 1997
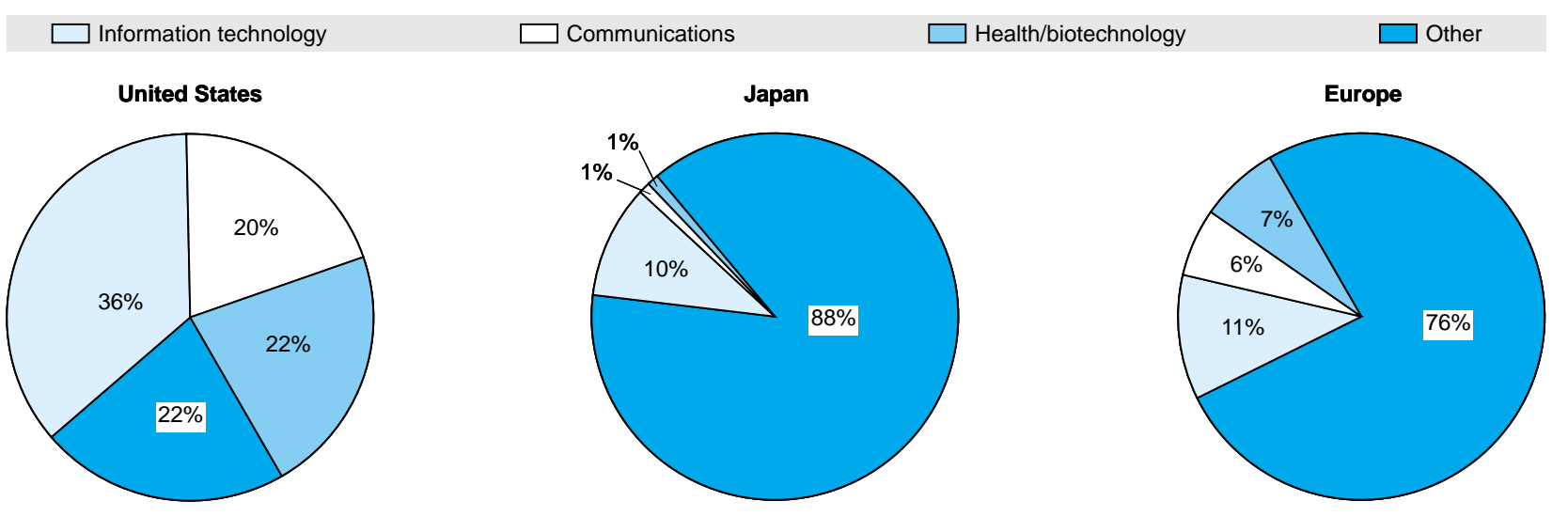

Source: OECD, based on data from European Venture Capital Association; MITI (Japan); CVCA (Canada); NVCA (United States). 


\section{Figure 21 Revealed Comparative Advantage by Technology Intensity}

Contribution to the manufacturing trade balance, 1996

As a percentage of manufacturing trade

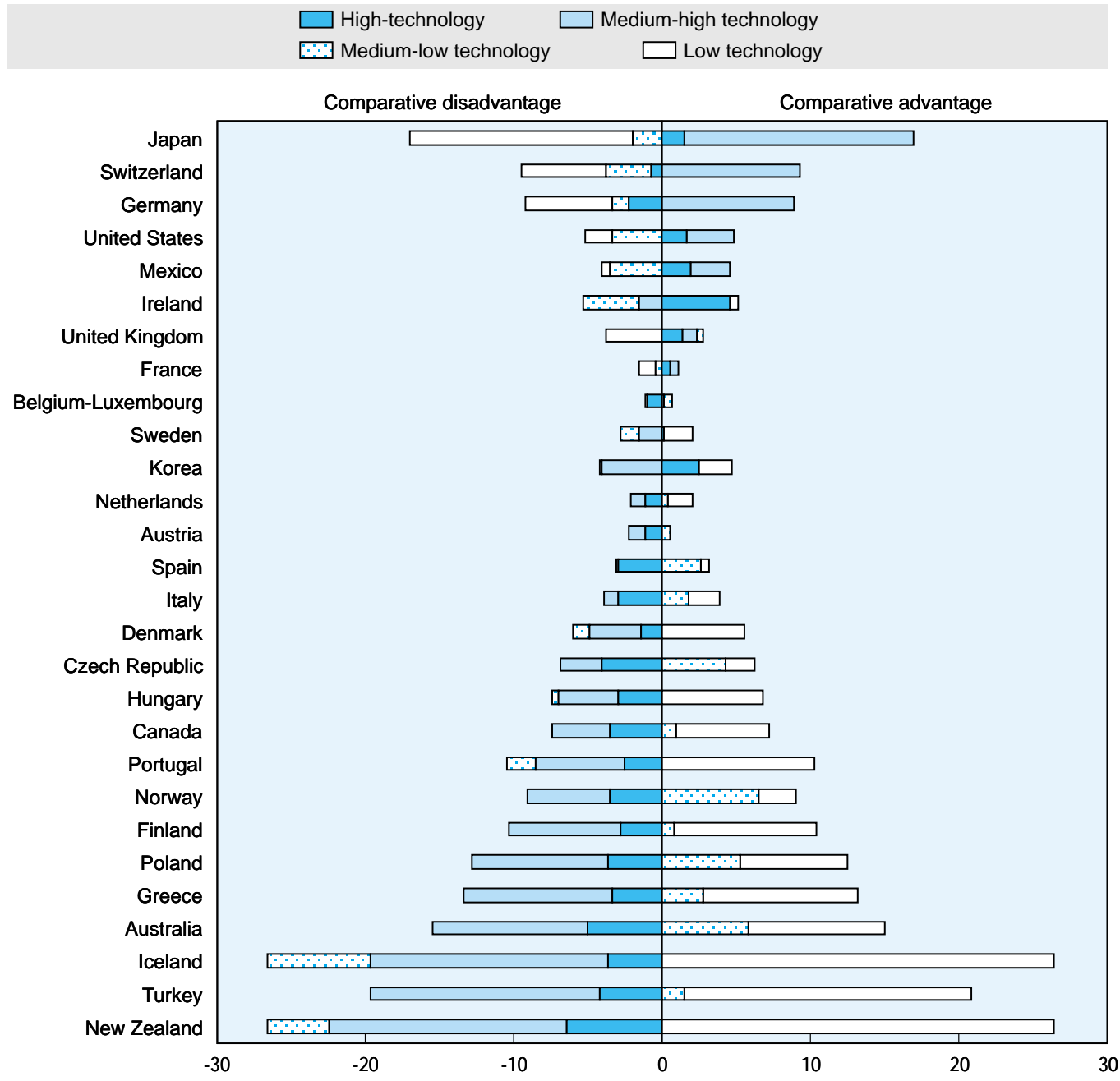

Source: OECD. 


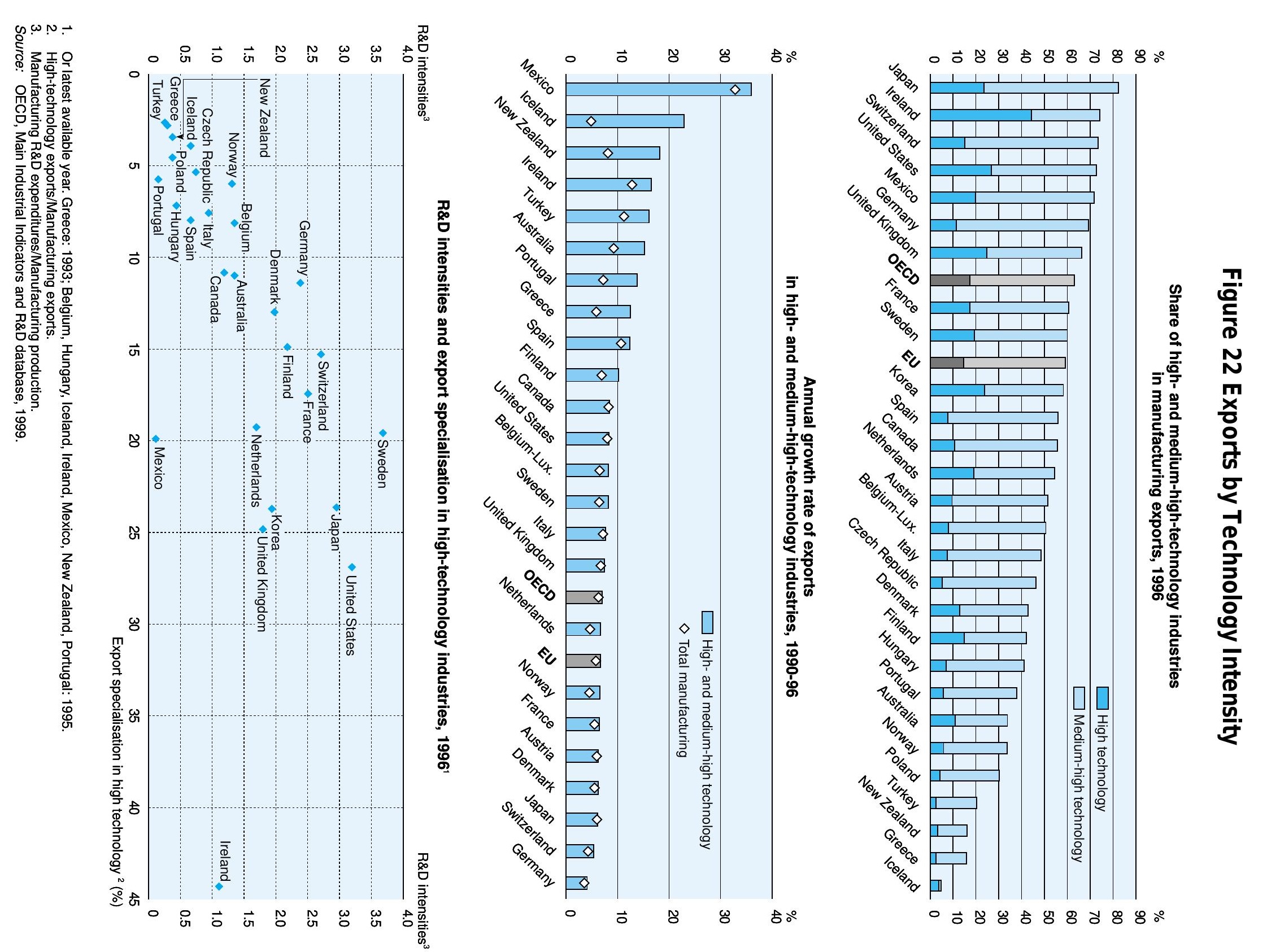



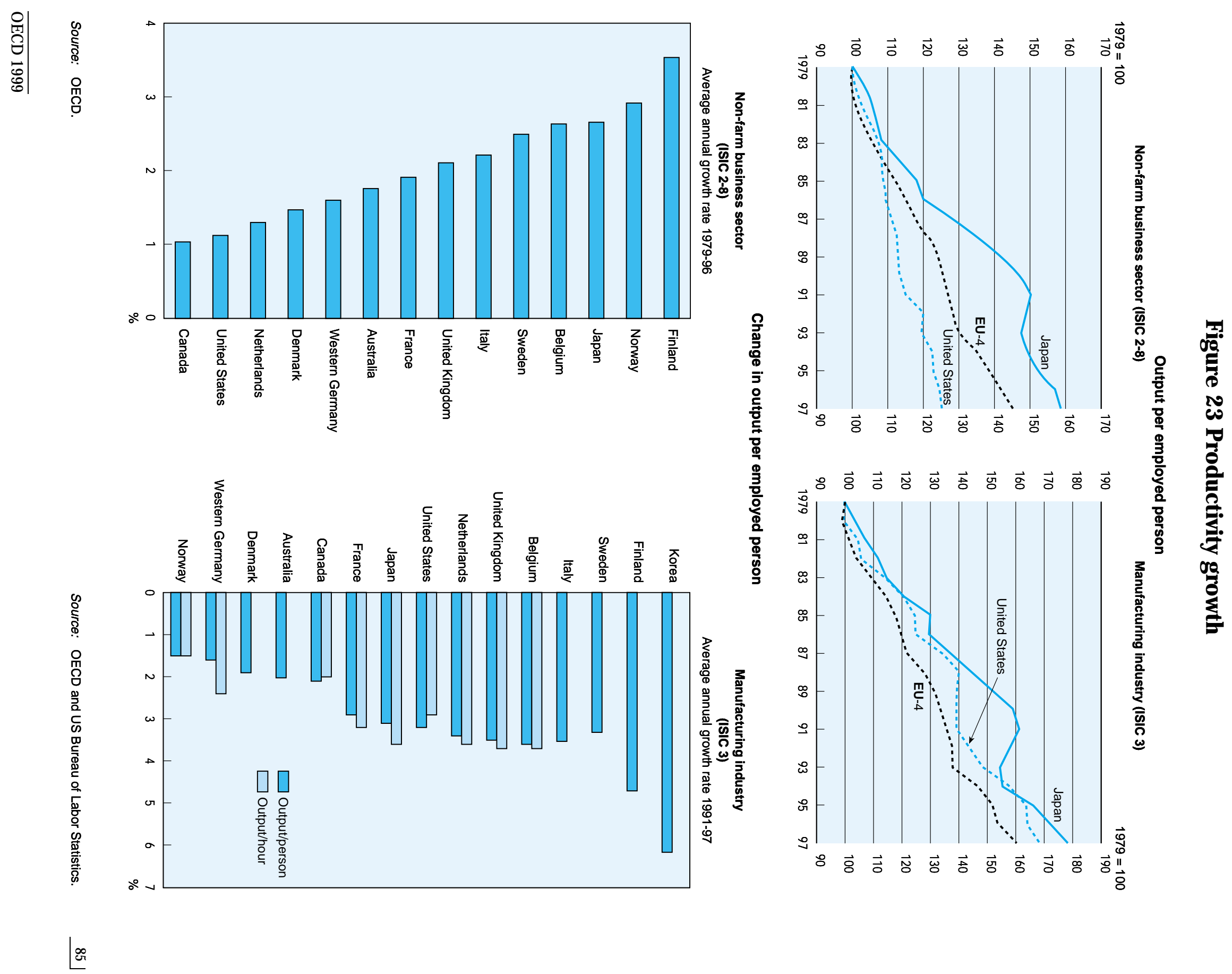


\section{Figure 24 Unit labour costs}

\section{Relative trade-weighted unit labour costs by industry, 1996} $1990=100$, US dollar basis
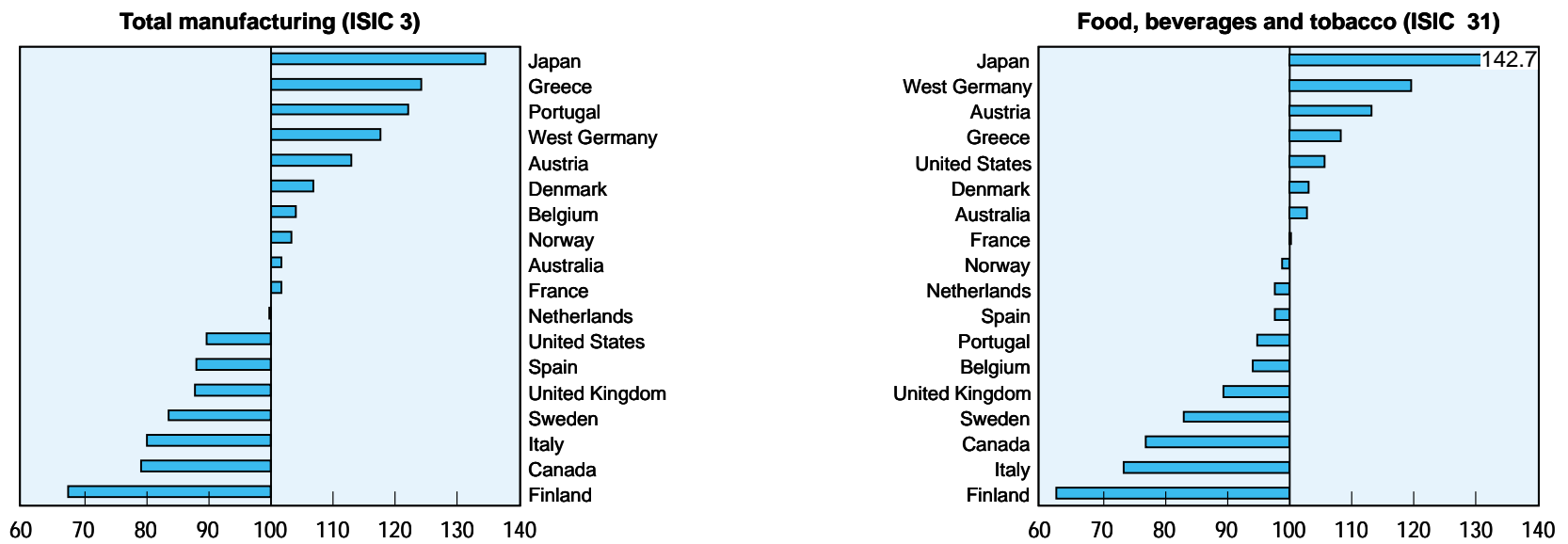

Textiles, footwear and leather (ISIC 32)

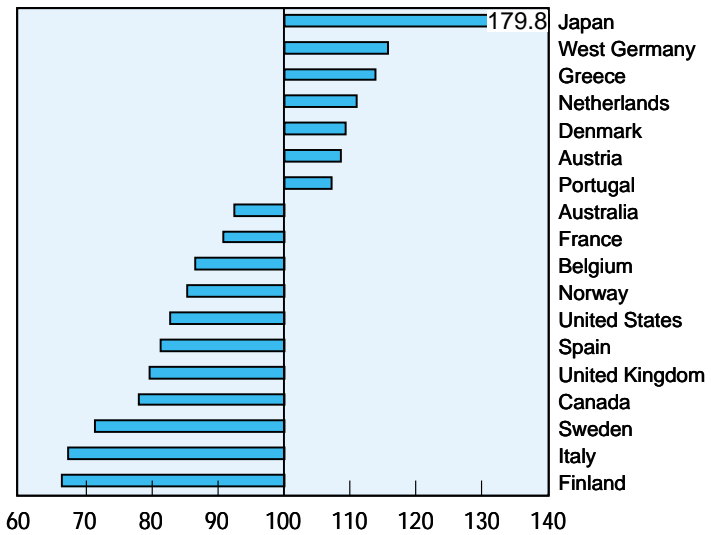

$\begin{array}{lllllllll}60 & 70 & 80 & 90 & 100 & 110 & 120 & 130 & 140\end{array}$

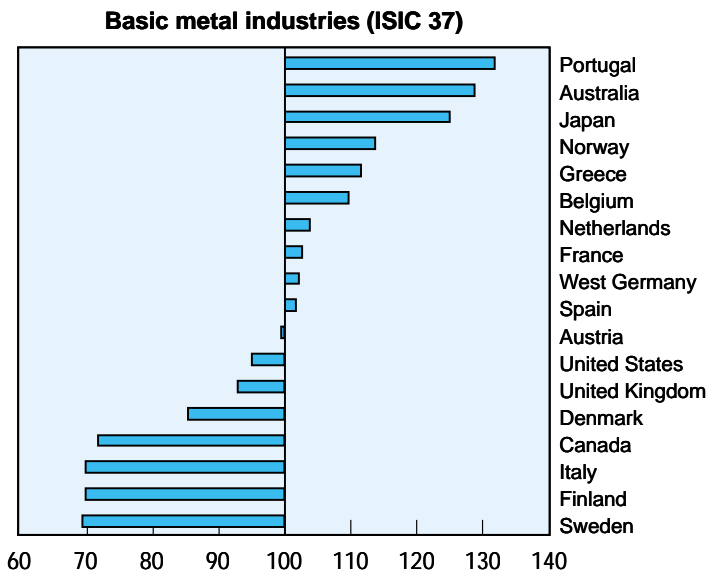

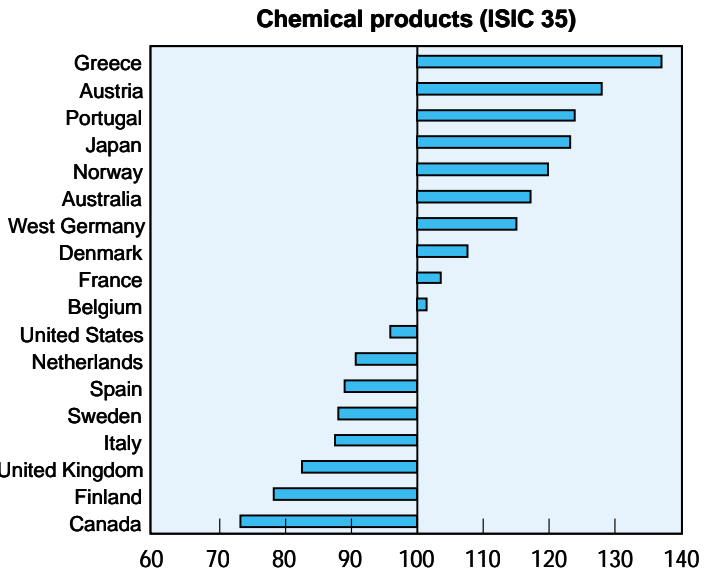

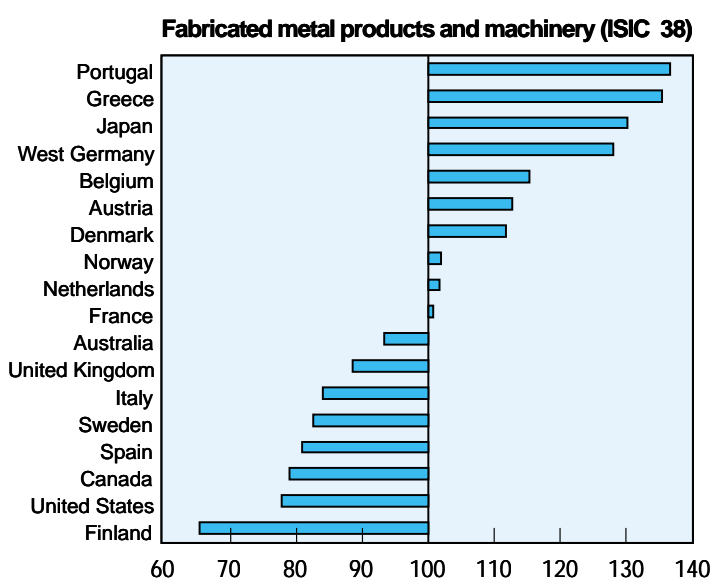

Source: OECD, STAN and Bilateral Trade databases, May 1999. 
Figure 25

Real Total Compensation per Employee

in the USA, Germany, Italy, the Netherlands

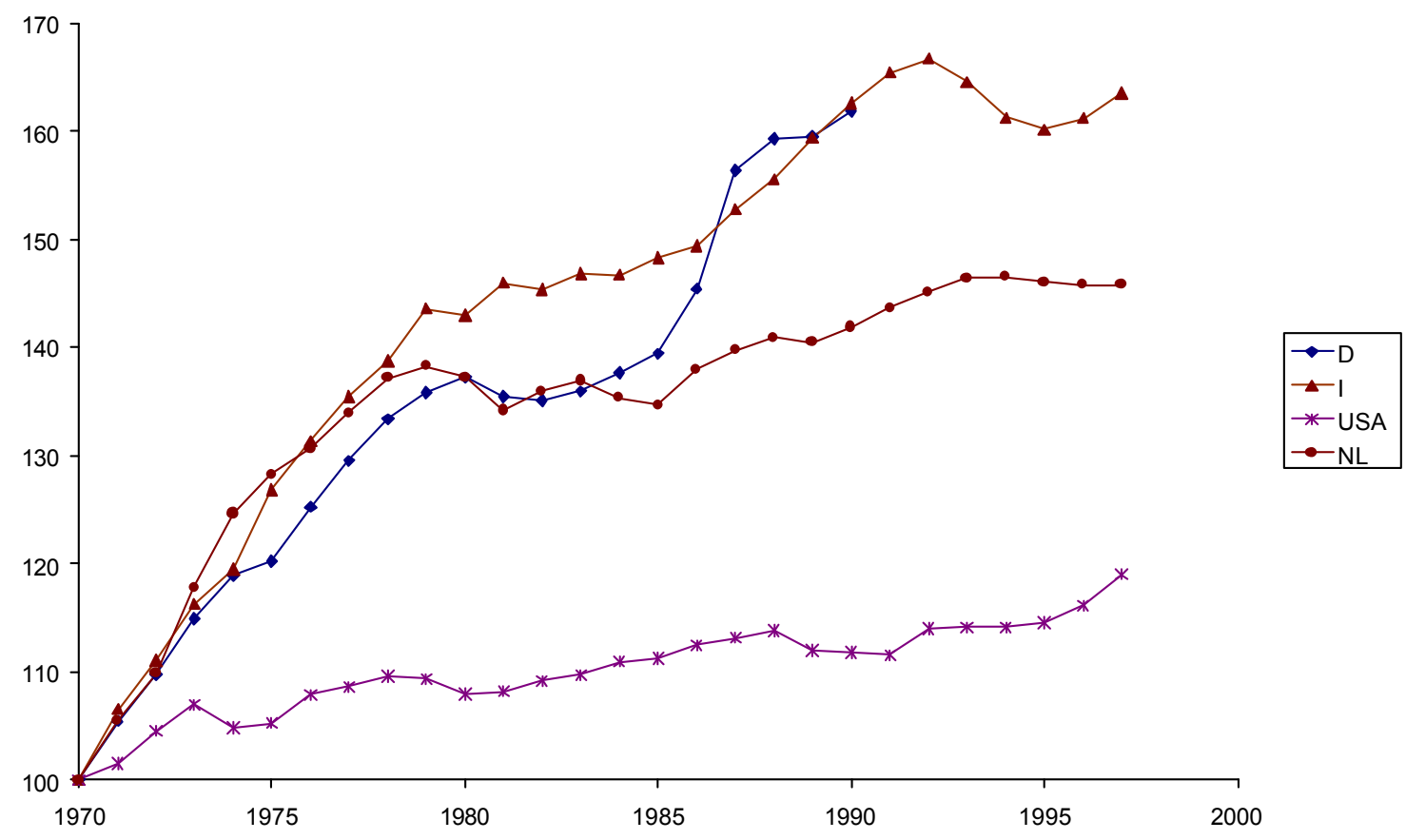

Bertola, Guiseppe. (2000) "Europe's Unemployment Problems." Unpublished manuscript. 
Figure 26

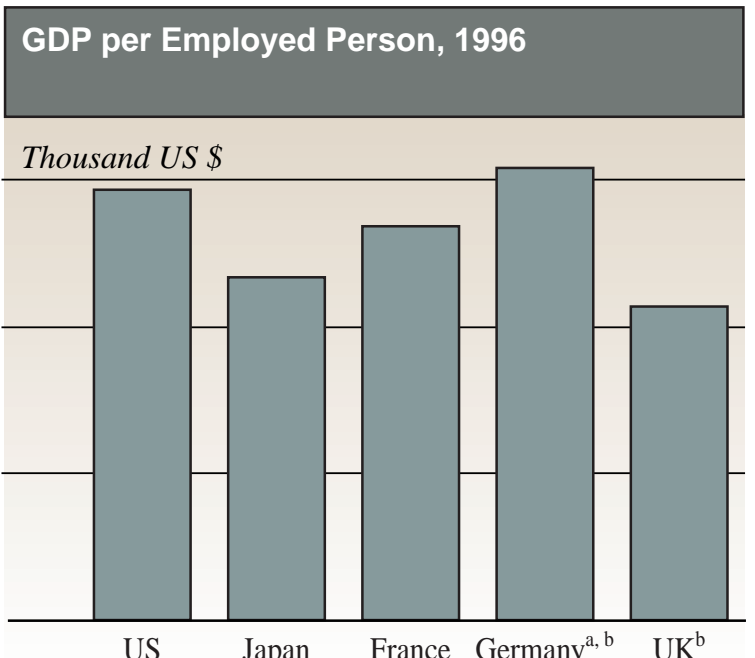

US

Japan

France Germany, ${ }^{\mathrm{a}, \mathrm{b}} \mathrm{UK}^{\mathrm{b}}$

\section{Average Hours Worked in Manufacturing} per Employee, 1997

Thousand hours

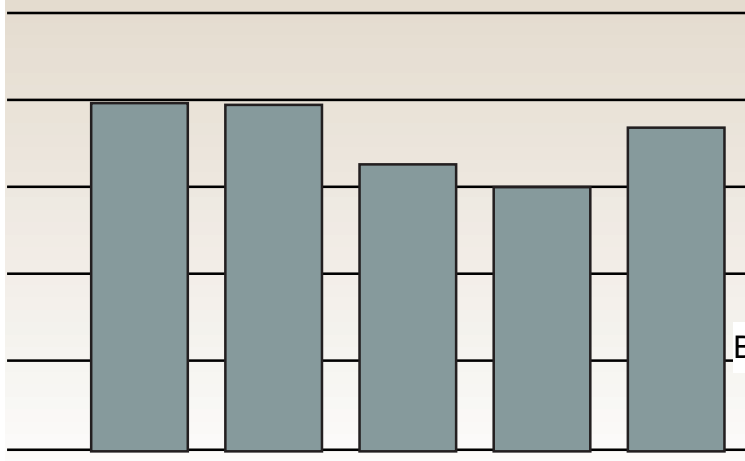

US
Japan France Germany UK
Manufacturing, $1997^{\mathrm{d}}$
Employment Growth, 1997
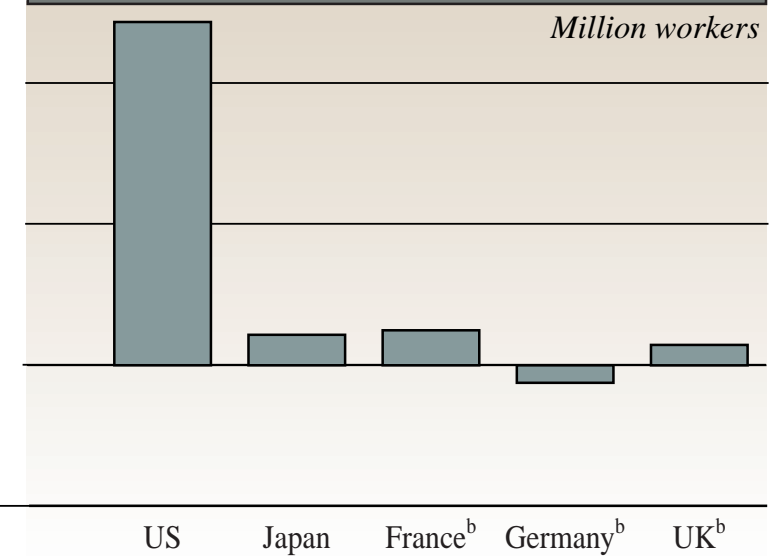

\section{Hourly Compensation in}

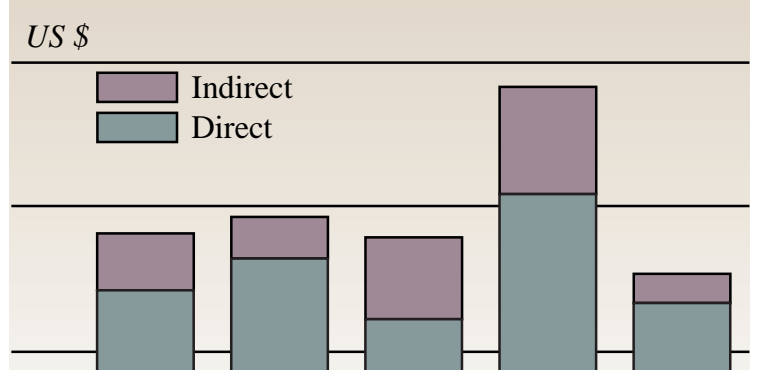

Bertola, Guiseppe. (2000) "Europe's Unemployment Problems." Unpublished manuscript.

Manufacturing and Services

Employment, 1997

Percent of total employment

$\square$ Manufacturing $\square$ Services

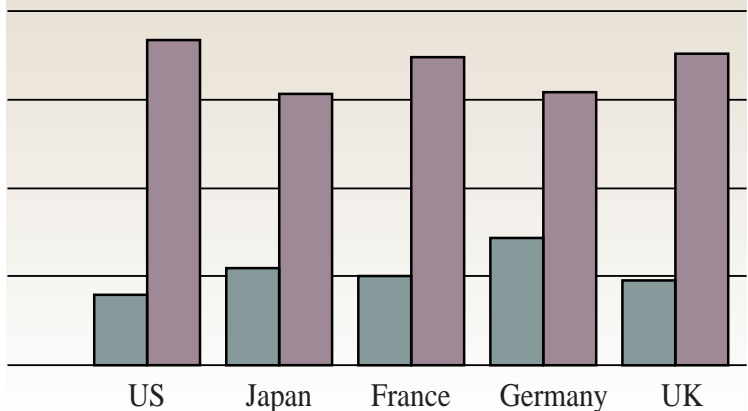

Unit Labor Costs in Manufacturing

in US Dollars

Index: $1986=100$
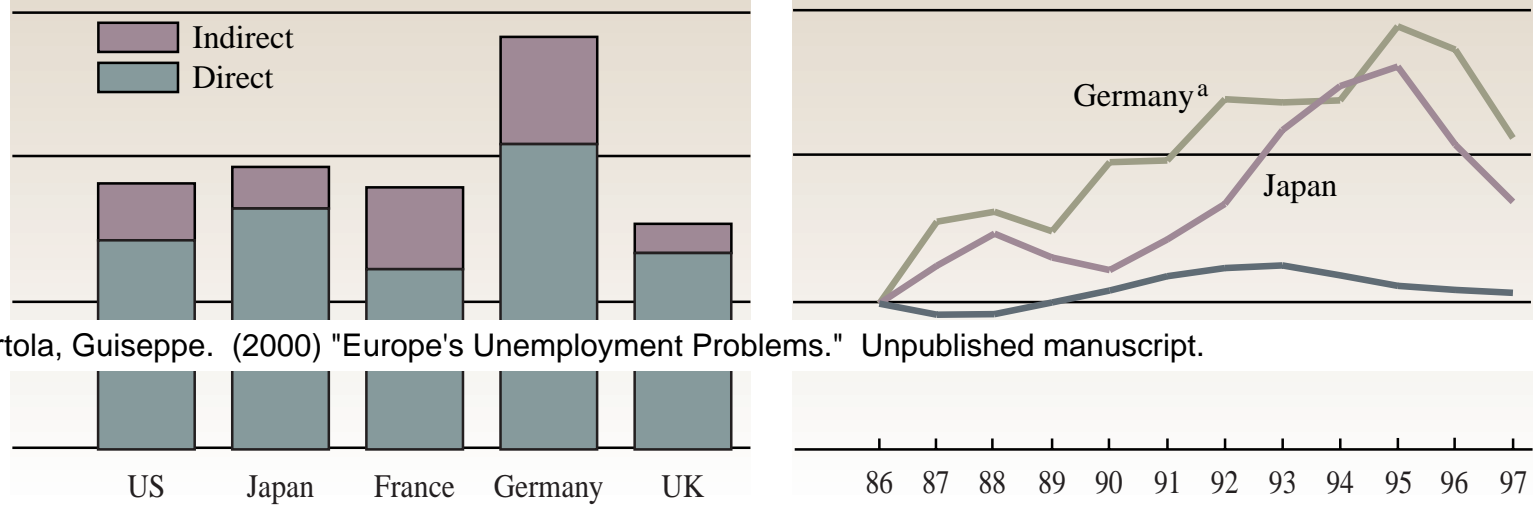

${ }^{\mathrm{a}}$ Western area only.

${ }^{\mathrm{b}} 1996$.

${ }^{c}$ Latest data available.
${ }^{\mathrm{d}}$ Labor costs for production workers. Hourly direct pay includes pay for time worked, pay for time not worked, bonuses, and the cost of any payments in kind. Hourly indirect pay includes employer expenditures for legally required insurance programs and contractual and private benefit plans plus taxes on, minus subsidies of, payrolls or employme.

Source: CIA Handbook of International Economic Statistics (1999) 